\title{
Mollusks from the upper Shackleton Limestone (Cambrian Series 2), Central Transantarctic Mountains, East Antarctica
}

\author{
Thomas M. Claybourn, ${ }^{1,2}$ Sarah M. Jacquet, ${ }^{3}$ Christian B. Skovsted, ${ }^{4}$ Timothy P. Topper, ${ }^{4,5}$ \\ Lars E. Holmer, ${ }^{1,5}$ and Glenn A. Brock ${ }^{2}$ \\ ${ }^{1}$ Department of Earth Sciences, Palaeobiology, Uppsala University, Villav. 16, SE-75236, Uppsala <thomas.claybourn@geo.uu.se> \\ $<$ lars.holmer@pal.uu.se> \\ ${ }^{2}$ Department of Biological Sciences, Macquarie University, Sydney, NSW 2109 <glenn.brock@mq.edu.au> \\ ${ }^{3}$ Department of Geological Sciences, University of Missouri, Columbia, MO $65211<$ jacquets@ missouri.edu> \\ ${ }^{4}$ Department of Palaeobiology, Swedish Museum of Natural History, Box 5007, SE-104 05, Stockholm <christian.skovsted@nrm.se> \\ <timothy.topper@nrm.se> \\ ${ }^{5}$ Shaanxi Key laboratory of Early Life and Environments, State Key Laboratory of Continental Dynamics and Department of Geology, \\ Northwest University, Xi'an 710069, China <timothy.topper@nwu.edu.cn>
}

\begin{abstract}
An assemblage of Cambrian Series 2, Stages 3-4, conchiferan mollusks from the Shackleton Limestone, Transantarctic Mountains, East Antarctica, is formally described and illustrated. The fauna includes one bivalve, one macromollusk, and 10 micromollusks, including the first description of the species Xinjispira simplex Zhou and Xiao, 1984 outside North China. The new fauna shows some similarity to previously described micromollusks from lower Cambrian glacial erratics from the Antarctic Peninsula. The fauna, mainly composed of steinkerns, is relatively low diversity, but the presence of diagnostic taxa, including helcionelloid Davidonia rostrata (Zhou and Xiao, 1984), bivalve Pojetaia runnegari Jell, 1980, cambroclavid Cambroclavus absonus Conway Morris in Bengtson et al., 1990, and bradoriid Spinospitella coronata Skovsted et al., 2006, as well as the botsfordiid brachiopod Schizopholis yorkensis (Ushatinskaya and Holmer in Gravestock et al., 2001), in the overlying Holyoake Formation correlates the succession to the Dailyatia odyssei Zone (Cambrian Stages 3-4) in South Australia.
\end{abstract}

\section{Introduction}

During the early Cambrian, East Antarctica was sutured between the now southern coast of Australia, Southeast Africa, and India and located at tropical latitudes (Brock et al., 2000; Torsvik and Cocks, 2013a, b). The Shackleton Limestone crops out meridionally and episodically along the Central Transantarctic Mountains (Fig. 1). While the true thickness of this carbonate unit remains uncertain (Myrow et al., 2002), it is estimated to be up to 2,000 $\mathrm{m}$ thick in places (Laird et al., 1971; Burgess and Lammerink, 1979). The unit consists of many lithofacies including sandy carbonates, pure limestones, and archaeocyathmicrobialite bioherms (Rees et al., 1989; Myrow et al., 2002). The newly recovered fauna from measured stratigraphic sections through autochthonous exposures of the Byrd Group, central Transantarctic Mountains, includes archaeocyaths, brachiopods, bradoriid arthropods, cambroclavids, chancelloriids, hyoliths, sponge spicules, and tommotiids. This paper focusses on descriptions and biostratigraphy of eight helcionelloids, two pelagiellids, one scenellid, and the bivalve Pojetaia runnegari Jell, 1980. Helcionelloids are typical components of 'small shelly fossil' (SSF) assemblages in lower Cambrian (Terreneuvian, Cambrian Series 2) strata around the world (Bengtson, 2004; Kouchinsky et al., 2012). Widespread phosphatized steinkerns of micromorphic univalved helcionelloids appear in the pre-trilobitic Terreneuvian (Khomentovsky et al., 1990; Kouchinsky et al., 2012) and range through to the Early Ordovician (Gubanov and Peel, 2001; Peel and Horný, 2004).

The taxonomic position of helcionelloids remains unresolved, with numerous authors suggesting different affinities and phylogenetic relationships (Parkhaev 2008, table 3.1). Early efforts placed some asymmetrically coiled helcionelloids in the late Paleozoic macluritid gastropods and bilaterally symmetrical forms with the monoplacophoran tryblidiids-then considered a 'primitive' gastropod taxon (Knight, 1952). Helcionelloids have also been suggested by some authors to be basal to the rest of the Gastropoda (e.g., Golikov and Starobogatov, 1975; Runnegar and Jell, 1976; Parkhaev, 2017a); a polyphyletic approach was proposed by other authors, with some helcionelloids considered ancestral to the major groups of mollusks (Runnegar and Jell, 1976, fig. 4; Runnegar, 1983, fig. 1) while others (the superfamily Helcionellacea Wenz, 1938) were referred to the monoplacophorans. Problems with these classification schemes are apparent, as a diagnostic criterion of the gastropods is torsion (Salvini-Plawen, 1980; Ponder and Lindberg, 1997), a characteristic obvious only in soft anatomy and never convincingly demonstrated in any helcionelloid taxon (but see Runnegar, 1981). A monoplacophoran affinity is also difficult to demonstrate as helcionelloids invariably lack the serially repeated muscles scars on the shell interior 

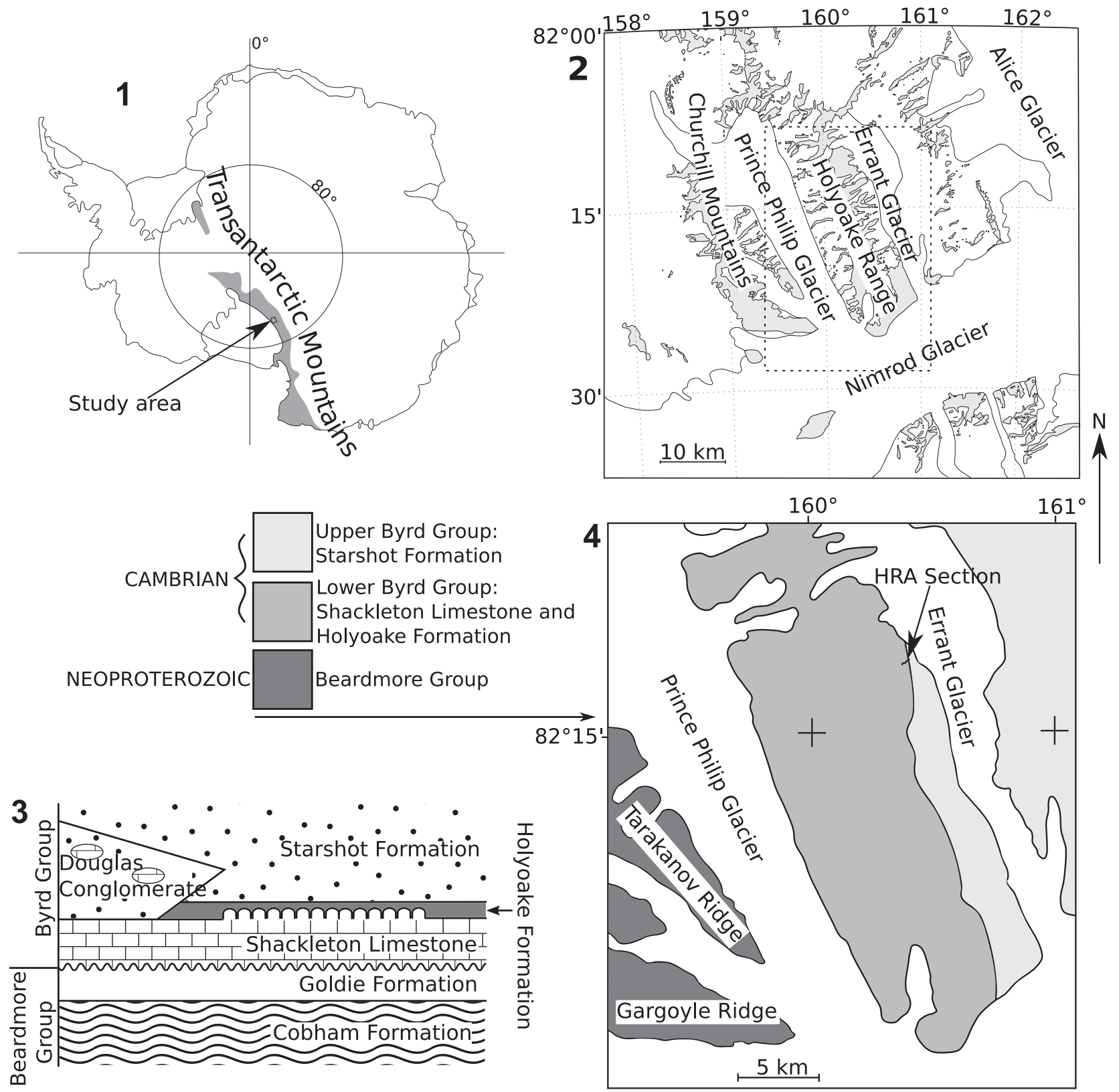

Figure 1. (1) Map of Antarctica showing approximate extent of the Transantarctic Mountains and area shown in (2). (2) Map of Nimrod Glacier, Holyoake Range, and Churchill Mountains. (3) Generalized relationship of Cambrian (Byrd Group) and Neoproterozoic (Beardmore Group) rock units of the Holyoake Range, adapted from Myrow et al. (2002). (4) Simplified geological map of the Holyoake Range, adapted from Myrow et al. (2002).

reflecting the muscle attachment common to all extant monoplacophorans (Lindberg, 2009). Lindsey and Kier (1984) hypothesized a separate paraphyletic class for some asymmetrical helcionelloid mollusks (the Paragastropoda) on the basis that they lacked evidence of both torsion and serially repeated muscle scars, which included the pelagiellids. However, the asymmetrically coiled pelagiellids are perhaps the best candidates for inclusion in the gastropods. Preserved features such as muscle scars similar to those found in torted gastropods (Landing et al., 2002, fig. 9), a large mantle cavity, and potential anal notch have been inferred by some authors as indirect evidence of torsion (Landing et al., 2002). The class Helcionelloida Peel, 1991a was erected to include bilaterally symmetrical forms, excluding asymmetrical forms of the Paragastropoda.
Recognized sinistral and dextral asymmetrical deviations from typically symmetric forms remain within Helcionelloida (Gubanov and Peel, 2000). Recent systematic treatment of pelagiellids has them assigned to the helcionelloids (e.g., Skovsted and Peel, 2007; Topper et al., 2009; Wotte and Sundberg, 2017) or to the gastropods (e.g., Landing et al. 2002; Parkhaev, 2007a, 2017a).

While many authors have worked on the paleobiology of the helcionelloids (e.g., Peel, 1991a; Brock, 1998; Parkhaev, 2000,2001 ), these and other SSFs can also be utilized in biostratigraphy, with certain caveats. Parkhaev in Gravestock et al. (2001) created loosely defined molluscan assemblage 'zones' for their work on the biostratigraphy of the lower Cambrian succession in the Stansbury Basin, South Australia. These were defined according to the presence of certain key taxa, and four 
'zones' were recognized (oldest to youngest): Pelagiella subangulata, Bemella communis, Stenotheca drepanoida, and Pelagiella madianensis 'zones.' Jacquet et al. (2017) criticized these molluscan biozones noting they have very poorly defined boundaries and are based on poorly preserved, long-ranging taxa with considerable overlapping ranges. Close inspection of the data provided by Gravestock et al. (2001) reveals clear temporal discrepancies between the sections on Yorke and Fleurieu peninsulas (see Jacquet et al., 2017, p. 1093-1094 for details; Betts et al., 2016a).

Broad biostratigraphic correlations of lower Cambrian rocks have proven difficult due to strong provincialism and facies dependence in faunas (Landing, 1992; Mount and Signor, 1992; Steiner et al., 2004, 2007; Landing et al., 2013; Jacquet et al., 2016a; Yun et al., 2016). Betts et al. (2016a, 2017) created regional SSF biozones for the early Cambrian of South Australia and used mollusks as key accessory taxa. The choice of the primarily phosphatic tommotiid taxa Kulparina rostrata Conway Morris and Bengtson in Bengtson et al., 1990, Micrina etheridgei (Tate, 1892), and Dailyatia odyssei Evans and Rowell, 1990 to define these zones avoided some of the taxonomic and taphonomic problems associated with facies dependence and incomplete steinkern preservation in lower Cambrian carbonates (Mount and Signor, 1992; Jacquet et al. 2016a). Molluskan steinkerns are also often difficult to identify accurately to species level due to lack of information on the shell exterior, especially micro-ornament and other surficial features, an important criterion for species differentiation (Skovsted, 2006a; Betts et al., 2016b; Jacquet and Brock, 2016). The base of Cambrian Series 2, Stage 3, remains unresolved, although the first appearance datum of trilobites occurs around this boundary (see Babcock et al., 2017 and Zhang et al., 2017 for recent reviews). The use of SSFs, including mollusks, for establishing regional bases of Series 2 and Stage 3 has been put forward by some authors, for example, the Pelagiella subangulata taxonrange zone for South China (Steiner et al., 2007, 2011).

The fossils described herein are almost exclusively steinkerns of calcium phosphate, with occasional external molds. Primary mineralized or secondarily replaced shells are not present, but mineral imprints are present on the exterior of some steinkerns, which correspond to a variety of calcitic or aragonitic crystal morphologies. Examples of this, among others, include polygonal imprints that are interpreted as calcitic semi-nacre (Kouchinsky, 2000; Vendrasco et al., 2010; Vendrasco and Checa, 2015) and elongated crystal laths that are interpreted to be aragonitic (Landing and Bartowski, 1996; Kouchinsky, 2000; Landing et al., 2002; Vendrasco et al., 2010; Li et al., 2017). The chemical formation of phosphatic steinkerns is biased toward micromorphic forms (Creveling et al., 2014), suggesting some helcionelloid fossils might represent the juvenile shells (protoconchs) of macroscopic univalved mollusks (see Martí-Mus et al., 2008; Jacquet and Brock, 2016; Jacquet et al., 2016b). One of the first quantitative analyses of the fidelity of steinkern representation of the original shell identified the size of the umbilicus of anisostrophically coiled Ordovician mollusks as an indicator of the size of the original organism (Dattilo et al., 2016. This indicated the size of the steinkerns of the micromolluskan fauna studied was taphonomically, not ecologically, controlled. The basic size of the steinkern therefore cannot be used to indicate ontogeny, and morphological differences between two steinkerns of the same size may not indicate taxonomically meaningful differences. The term 'teilsteinkern' was introduced to describe incomplete internal molds (Dattilo et al., 2016).

Some evidence suggests that the preservation of phosphatic steinkerns is tied to particular lithologies and depositional processes. Phosphate replacement and coating of originally calcareous fossils was related to phosphate precipitation and intense denitrification within sediments or above an oxygen minimum zone (Landing 1992; Landing et al., 2002). Subsequently, Jacquet et al. (2016a) noted the occurrence of abundant micromolluskan residues was linked to facies characterized by sediment reworking (i.e., tempestites) or low sedimentation rates (i.e., firmgrounds and true hardgrounds).

Geological setting and previous work.-The bulk of fossil material recovered is derived from an archaeocyath-rich biohermal unit near the top of a stratigraphic section (HRA) measured through the Shackleton Limestone and the overlying dark nodular carbonates and interbedded calc-siltsones of the Holyoake Formation. These rock units make up part of the Byrd Group (Figs. 1, 2), which crops out along the Central Transantarctic Mountains (Myrow et al., 2002). The deposition of the Shackleton Limestone was interrupted by the Ross Orogenic events, involving a change in the East Antarctic plate margin from passive to orogenic subduction regime (Boger and Miller, 2004). Subsidence resulted in a brief marine transgression across the continental shelf and deposition of the deeper-water argillaceous Holyoake Formation (Goodge et al., 1993, 2004; Myrow et al., 2002) at approximately 515-510 Ma (Paulsen et al., 2007). This was followed by a shallowing succession and ?syn-orogenic deposition of fine to medium calcareous sandstones of the Starshot Formation and overlying boulder conglomerates of the Douglas Conglomerate (Rowell et al., 1988a; Myrow et al., 2002; Goodge et al., 2004; Paulsen et al., 2007). Stratigraphic sections through the Shackleton Limestone have proven difficult to interpret into a coherent in situ stratigraphy due to pervasive folding and faulting (including fault repetition) of the carbonate-dominated succession, the result of tectonism associated with the Ross Orogeny (Paulsen et al., 2007).

Paleontological studies on parautochthonous lower Cambrian rocks from the Shackleton Limestone have largely focused on trilobites (Palmer and Gatehouse, 1972; Palmer and Rowell, 1995) and archaeocyaths (Debrenne and Kruse, 1986, 1989). In terms of other clades, only tommotiids (Evans and Rowell, 1990), the helcionelloid mollusk Marocella mira Evans, 1992, and a single bradoriid arthropod species, Bicarinellata evansi Rode et al., 2003, have been formally described systematically. Rowell et al., (1988b, figs. G, L, P, Q) also illustrated some taxa, including an elkaniid-like lingulid, Lingulella sp. and the mollusk Latouchella sp., as well as an unnamed 'euomphalid mollusk' but without formal description. Brachiopods, mollusks, tommotiids, and other SSFs derived from allochthonous clasts redeposited in a Miocene glacial-marine succession on King George Island, near the tip of the Antarctic Peninsula, were probably originally deposited within sediments equivalent to the Shackleton Limestone (Wrona, 1989, 2003, 2004; Holmer 


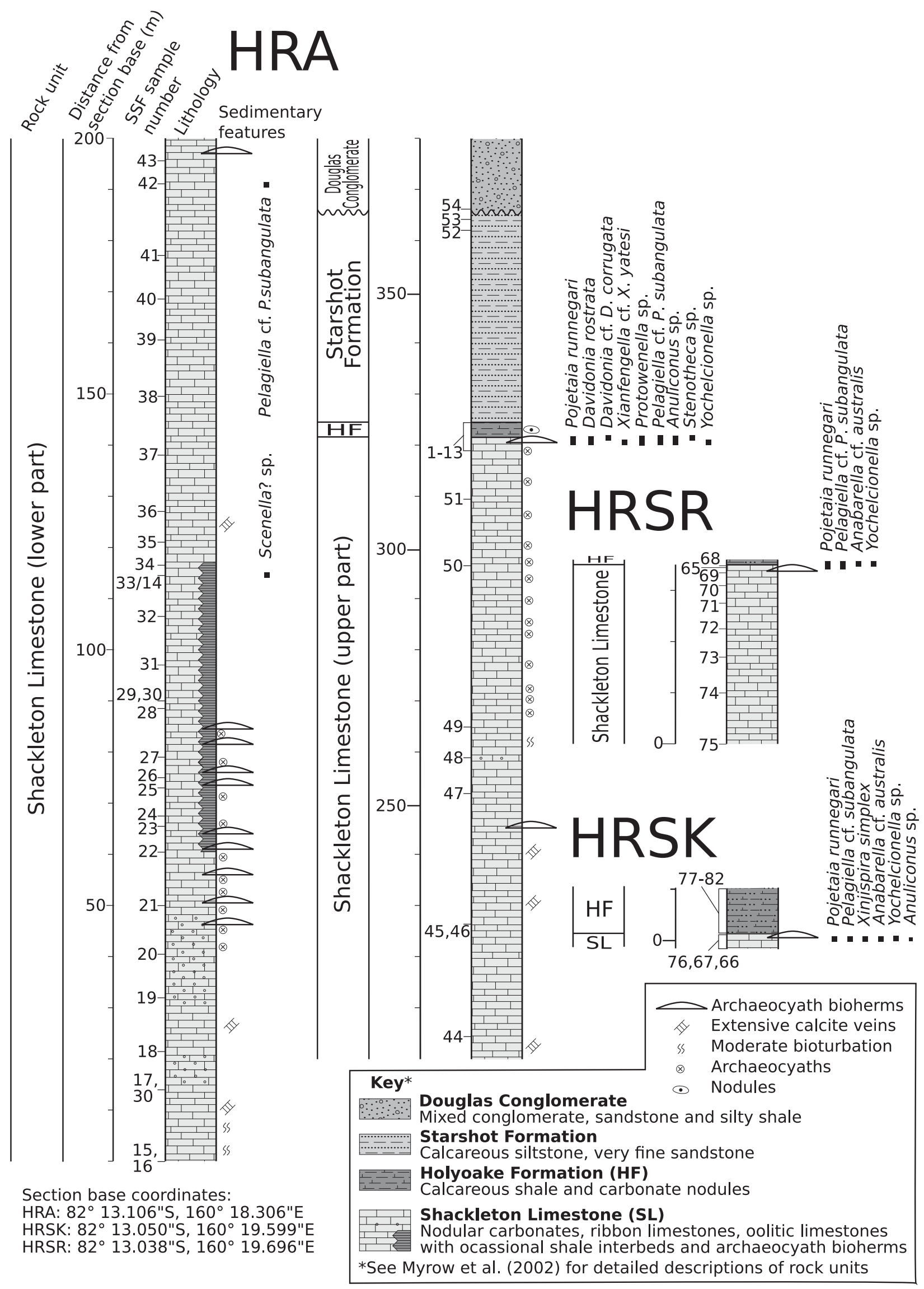

Figure 2. Sedimentary columns with micromollusk occurrences of measured sections of the Holyoake Range. HF $=$ Holyoake Formation; SL $=$ Shackleton Limestone. 
et al., 1996). These discoveries have formed the bulk of knowledge of lower Cambrian faunas from Antarctica and confirm strong biostratigraphic and paleobiogeographic links with South Australia (Brock et al., 2000; Betts et al., 2016a, 2017), Northeast Greenland (Skovsted, 2004, 2006b), and North China (Yang et al., 2015) during Cambrian Series 2, Stages $3-4$.

\section{Stratigraphic correlation}

Antarctica.-Lower Cambrian limestone erratics have been recovered within early Miocene glaciomarine deposits of King George Island, north of the Antarctic Peninsula (Gaździcki and Wrona, 1986; Wrona, 1989); these contain a diverse fauna of poriferan spicules and chancellorid, sachitiid, and tommotiid sclerites (Wrona, 2004), organophosphatic brachiopods (Holmer et al., 1996), bradoriids and phosphatocopids (Wrona, 2009), and mollusks (Wrona, 2003). The molluskan fauna from the erratics is similar to the Shackleton Limestone samples recovered from the Holyoake Range, including the genera Yochelcionella Runnegar and Pojeta 1974, Anabarella Vostokova, 1962, and Pelagiella (Matthew, 1895) (Wrona, 2003). The erratics most likely belong to the Shackleton Limestone and host the age-diagnostic tommotiid Dailyatia odyssei (Evans and Rowell, 1990; Wrona, 2004; Skovsted et al., 2015).

South Australia.-Previous studies suggesting a link between the Shackleton Limestone and South Australia were based on relatively few in situ samples from Antarctica, particularly of SSFs (see Brock et al., 2000; Topper et al., 2011; Yang et al., 2015). Biostratigraphic correlation has previously been based on trilobites (Palmer and Gatehouse, 1972; Palmer and Rowell, 1995). Palmer and Rowell (1995) tentatively assigned their six assemblages of trilobites to be from Atdabanian to Toyonian in age, and their assemblage 4 was correlated to the Pararaia janae zone of South Australia on the basis of co-occurrence of Balcoracania (Jell in Bengtson et al., 1990). Paterson and Brock (2007) described Yunnanocephalus macromelos from the Mernmerna Formation, indicating a link between Palmer and Rowell's (1995) Assemblage 1 (which contains members of the genus) and the Pararaia bunyenrooensis Zone. Caution was suggested in these ages due to few easily compared species (Palmer and Rowell, 1995, p. 4). Debrenne and Kruse $(1986,1989)$ indicated an Atdabanian-Botoman age for Antarctic archaeocyaths and considered most species to be found in common with the Wilkawillina and Ajax Limestones (Debrenne and Kruse, 1989, p. 24). Accurately correlating the Shackleton Limestone on the basis of the molluskan fauna alone is problematic due to issues already discussed with steinkern formation (Creveling et al., 2014; Jacquet et al., 2016a) and long stratigraphic ranges of helcionelloids (Landing, 1988; Geyer and Shergold, 2000; Jacquet et al., 2017; Zhang et al., 2017). This problem was discussed by Betts et al. (2017, p. 202) and Jacquet et al. (2017) in reference to the informal molluskan assemblage biozonations in Gravestock et al. (2001). A close correlation to the Dailyatia odyssei Zone in South Australia is strengthened by the shared presence of the accessory taxa
Cambroclavus absonus Conway Morris in Bengtson et al., 1990 (Skovsted et al., 2006, fig. 2) in the biohermal facies at the top of the Shackleton Limestone and Spinospitella coronata in the overlying Holyoake Formation, both of which co-occur in the $D$. odyssei Zone with accessory taxon Schizopholis (=Karathele) yorkensis (Ushatinskaya and Holmer in Gravestock et al., 2001). The presence of these taxa exclude the biohermal unit from correlation with the underlying Micrina etheridgei Zone, in which the steinkerns of the mollusks Pojetaia runnegari, Pelagiella, Anabarella, and Davidonia Parkhaev, 2017b also occur (Betts et al., 2017, figs. $3,4,7,8,12$ ). Xianfengella, Yochelcionella, and Stenotheca are all restricted to the D. odyssei Zone in South Australia, allowing for stronger correlation (Betts et al., 2017, figs. 5, 10, 12). Protowenella Runnegar and Jell, 1976 is also known from the Cambrian Series 3 in Australia (Runnegar and Jell, 1976; Brock, 1998; Vendrasco et al., 2010), as well as Cambrian Series 2, Stage 4 (Smith et al., 2015), but the utility of this taxon in correlation with South Australia is doubtful due to problems with consistent identification.

The Shackleton Limestone fauna has most similarity with the Mernmerna Formation in the Arrowie Basin, which shares the micromollusks Pojetaia runnegari, Davidonia, Pelagiella, Anabarella, Stenotheca Hicks, 1872, and Xianfengella He and Yang, 1982 (Topper et al., 2009). The macromollusk Marocella mira not reported in this study is also present in the upper Mernmerna Formation (Topper et al., 2009; Jacquet and Brock, 2016) and the Shackleton Limestone that outcrops in the Churchill Mountains (Evans, 1992). The Ajax Limestone in the Arrowie Basin also contains Davidonia and Anabarella steinkerns as well as Pelagiella subangulata (Tate, 1892) (Betts et al., 2016a, fig. 2). Pojetaia runnegari has also been reported from the Ajax Limestone (Bengtson et al., 1990, fig. 6) although the range extends down into the underlying $M$. etheridgei Zone. The Shackleton Limestone thus strongly correlates with the D. oddysei zone in the upper Ajax Limestone (Betts et al., 2016a, fig. 2). Yochelcionella chinensis Pei, 1985 has also been reported from the younger Oraparinna Shale (Runnegar in Bengtson et al., 1990) of the Pararaia janeae Zone (Jago et al., 2012).

Highly diverse assemblages of micromollusks have been reported from the lower Cambrian Stansbury Basin (Bengtson et al., 1990; Gravestock et al., 2001), many of which also occur in the Shackleton Limestone. Davidonia rostrata (Zhou and Xiao, 1984), Pojetaia runnegari, as well as the genera Anuliconus Parkhaev in Gravestock et al., 2001, Anabarella, Pelagiella, and Stenotheca occur in the uppermost Kulpara Formation and disconformably overlying Parara Limestone in the western Stansbury Basin (Bengtson et al., 1990; Parkhaev in Gravestock et al., 2001), indicating long stratigraphic ranges of limited correlation potential. Xianfengella yatesi Parkhaev in Gravestock et al., 2001 has a more restricted occurrence, in the Parara Limestone at Yorke Peninsula (Parkhaev in Gravestock et al., 2001). Betts et al. (2017, fig. 22) identified the D. odyssei Zone in the Parara Limestone at Horse Gully on Yorke Peninsula. A condensed Kulparina rostrata Zone and overlying Micrina etheridgei Zone occurr in the disconformably underlying Kulpara Formation (Betts et al., 2017, p. 202). 
North China. - Cambrian Series 2 strata from North China are divided into three biozones: the informal Stenotheca drepanoida-Pelagiella madianensis Biozone (Feng et al., 1994), considered equivalent to the Pararaia janeae trilobite zone of South Australia (Yun et al., 2016), and the overlying Redlichia and Redlichia chinensis informal trilobite zones (Yun et al., 2016). Mollusks from the Cambrian Series 2, Stages 3-4, Xinji Formation in Shaanxi Province, Henan Province, and Anhui Province on the southwestern, southern, and southeastern margins of the North China Platform, respectively, can be closely correlated to the Shackleton Limestone based on shared genera Stenotheca, Pelagiella, Yochelcionella, Yu and Rong, 1991, and Anabarella and species Xinjispira simplex, Pojetaia runnegari, and Davidonia rostrata (He et al., 1984; Zhou and Xiao, 1984; He and Pei, 1985; Pei, 1985; Li and Zhou, 1986; Yu and Rong, 1991; Feng et al., 1994; Yun et al., 2016). The presence of Xinjispira simplex in the Shackleton Limestone represents the first discovery of the species outside North China and helps strengthen this correlation. Putative Protowenella steinkerns are also known from the Xinji Formation (Zhou and Xiao, 1984). However, it should be noted that diagnostic muscle scars are not preserved on specimens from the Xinji Formation or Shackleton Limestone (and other putative pre-Series 3 specimens), making taxonomic assignment to this genus tentatative at this stage (Berg-Madsen and Peel, 1978; Brock, 1998).

South China.-Palmer and Rowell (1995) correlated their Trilobite Assemblage 1 (tentatively 'Atdabanian') to the Eoredlichia-Wutingaspis Zone of South China, which has significant overlap with the Dailyatia odyssei Zone of South Australia (Betts et al., 2017). The Eoredlichia-Wutingaspis Zone is equivalent to the Pelagiella subangulata Zone of East Yunnan and central Sichuan in South China (Steiner et al., 2007). The uppermost Shiyantou, Yuanshan (Yunnan Province) and upper Jiulaodong (Sichuan Province) formations of this zone have no shared helcionelloids for correlation to the Shackleton Limestone. The Yuanshan Formation of East Yunnan is predominantly siliciclastic and preserves phosphatic SSFs only in the lowermost phosphatic conglomerate unit, which contains SSFs of the Sinosachites flabelliformis-Tannuolina zhangwengtangi Zone (Steiner et al., 2001), immediately below the Pelagiella subangulata Zone (Steiner et al., 2007). This zone shares the taxon Xianfengella with the Shackleton Limestone only, in the Terreneuvian Yanjiahe Formation of Hubei (Guo et al., 2014) and Zhujianqing Formation of Yunnan (Anabarites trusulcatus-Protohertzina anabarica to Watsonella crosbyi zones) (Parkhaev and Demidenko, 2010).

Laurentia. - The SSF composition of eastern Laurentia suggests a continuous shelf margin during the early Cambrian (Skovsted, 2006b; Skovsted and Peel, 2010). Landing and Bartowski (1996) and Landing et al. (2002) reported diverse assemblages of SSFs from the Browns Pond Formation of the Taconic Allochthon of New York (Landing and Bartowski, 1996) and the 'Anse Maranda Formation' of Quebec (Landing et al., 2002), which contain a similar molluskan component of
Davidonia rostrata, Yochelcionella, and Pelagiella. The material from the Browns Pond Formation was collected from the Elliptocephala asaphoides assemblage, recognized as part of the Bonnia-Olenellus Zone by Siveter and Williams (1997). Also from Eastern Laurentia, the Forteau Formation of Newfoundland contains an abundant micromolluskan fauna (Skovsted and Peel, 2007), which shares Pojetaia runnegari, Davidonia, Stenotheca, and Pelagiella with the Shackleton Limestone. The formation also belongs to the Bonnia-Olenellus Zone as both trilobite genera occur there (Schuchert and Dunbar, 1934; Knight et al., 2017). Betts et al. (2017) recognized an overlap between the younger Olenellus Zone (the base of which is the same as the Bonnia-Olenellus Zone; Landing et al., 2013) and the uppermost part of the Dailyatia odyssei Zone of South Australia. The Kinzers Formation of Pennsylvania, of upper Cambrian Series 2 age, also contains steinkerns of Yochelcionella and Pelagiella (Atkins and Peel, 2008; Skovsted and Peel, 2010).

Northeast Greenland has lower Cambrian SSFs recognized as similar to those in South Australia and from the glacial erratics recovered from King George Island, Antarctica (Malinky and Skovsted, 2004; Skovsted, 2004; Skovsted and Holmer, 2005; Skovsted, 2006b). Skovsted (2004) reported a micromolluskan fauna from the Bastion Formation for Northeast Greenland, also correlated to the Bonnia-Olenellus Zone (Skovsted, 2006b, fig. 5.1-5.3), placing them as Dyeran in age of Laurentian regional scheme (Landing et al., 2013). The micromollusk fauna of the Bastion Formation is very similar to that found in the Shackleton Limestone and shared taxa include Davidonia rostrata, Pojetaia runnegari, Anabarella, Stenotheca, and Yochelcionella, (Skovsted, 2004) of which the latter four can be more loosely correlated at the generic level.

For western Laurentia, Skovsted (2006a) and Wotte and Sundberg (2017) provided systematic descriptions of lower Cambrian micromollusks from the Great Basins area. Pelagiella and Anabarella appear widespread across the province, with Pelagiella aff. P. subangulata occurring in the Emigrant Formation, Montenegro Member of the Campito Formation and the Combined Metals Member of the Pioche Formation, in rocks of upper Montezuman to Dyeran Stages (Wotte and Sundberg, 2017) given Cambrian Series 2, Stage 3 (Montezuman) and Stages 3-4 (Dyeran) (Peng et al., 2012).

\section{Materials and methods}

Fossils were collected in the Austral summer during five weeks of fieldwork in October-November, 2011 (by LEH, CBS, GAB) from measured stratigraphic sections (HRA, HRSK, and HRSR) in the Holyoake Range, Central Transantarctic Mountains (Figs. $1,2)$. The sections intersect the upper carbonate-dominated successions of the Shackleton Limestone, including inner shelf, shoal, and archaeocyath-microbialite bioherm facies, and the overlying and onlapping dark silty carbonates and argillites from the Holyoake Formation. The most diverse and abundant fossil materials are derived from well-exposed biohermal facies at the top of the Shackleton Limestone (Fig. 2). Stratigraphically, the sections are an extension of the section originally sampled and illustrated by Myrow et al. (2002). Phosphatic residues were extracted from the carbonate matrix with dilute $10 \%$ acetic 
acid solution following standard acid-leaching protocols (see Jeppsson et al., 1999). Images were taken with a Zeiss Supra 35 SEM at Uppsala University, a Hitachi S-4300 SEM at the Natural History Museum, Stockholm, and a PHENOM XL Benchtop SEM at Macquarie University.

Repository and institutional abbreviation.-All specimens are deposited at the Swedish Museum of Natural History (SMNH), Stockholm, Sweden.

\section{Systematic paleontology}

The phylogenetic relationships of the likely polyphyletic class Helcionelloida Peel, 1991a is still unresolved. Many simple, poorly preserved and minute cap-shaped steinkerns recovered from the Shackleton Limestone during this study are not dealt with here due to a lack of taxonomically informative features.

\section{Phylum Mollusca Cuvier, 1797 \\ Class Bivalvia Linnaeus, 1758 \\ Order and family uncertain}

\section{Genus Pojetaia Jell, 1980}

Type species._Pojetaia runnegari Jell, 1980, 'Salterella Limestone,' near Ardrossan, South Australia, by original designation. This likely corresponds to the Parara Limestone at Horse Gully, near Ardrossan, South Australia (cf. Jell, 1980, p. 234; Bengtson et al., 1990, fig. 4).

\section{Pojetaia runnegari Jell, 1980}

Figure 3

See Elicki and Gürsu (2009, p. 281-282) for a detailed synonymy.

1980 Pojetaia runnegari Jell, p. 235, figs. 1-3.

2004a Pojetaia runnegari; Parkhaev, p. 600, pl. 2, figs. 15-18. 2007 Pojetaia runnegari; Skovsted and Peel, p. 737, fig. 4 K, L. 2008 Pojetaia runnegari; Parkhaev, p. 38, fig. 3.4.

2009 Pojetaia runnegari; Elicki and Gürsu, p. 281, pl. 1, pl. 2, E-H.

2009 Pojetaia runnegari; Topper et al., p. 238, fig. 12 K-M.

2010 Pojetaia runnegari; Heuse et al., p. 107, fig. 2.14.

2011 Pojetaia runegari; Vendrasco et al., pl. 1-4.

2015 Pojetaia runnegari; Vinther, fig. 2H.

2016 Pojetaia runnegari; Yun et al., fig. 5M.

2017 Pojetaia runnegari; Betts et al., fig. 17O.

Holotype.-P59669, Paleontological collections, National Museum of Victoria, Melbourne, Australia. Internal mold of articulated valves, 'Salterella limestone,' lower Cambrian, South Australia.

Occurrence.-See Elicki and Gürsu (2009, p. 273) for a full review of global stratigraphic distribution. Distribution now includes Cambrian unnamed Series 2, Stages 3-4, of Newfoundland, Canada (Skovsted and Peel, 2007), and East Antarctica.

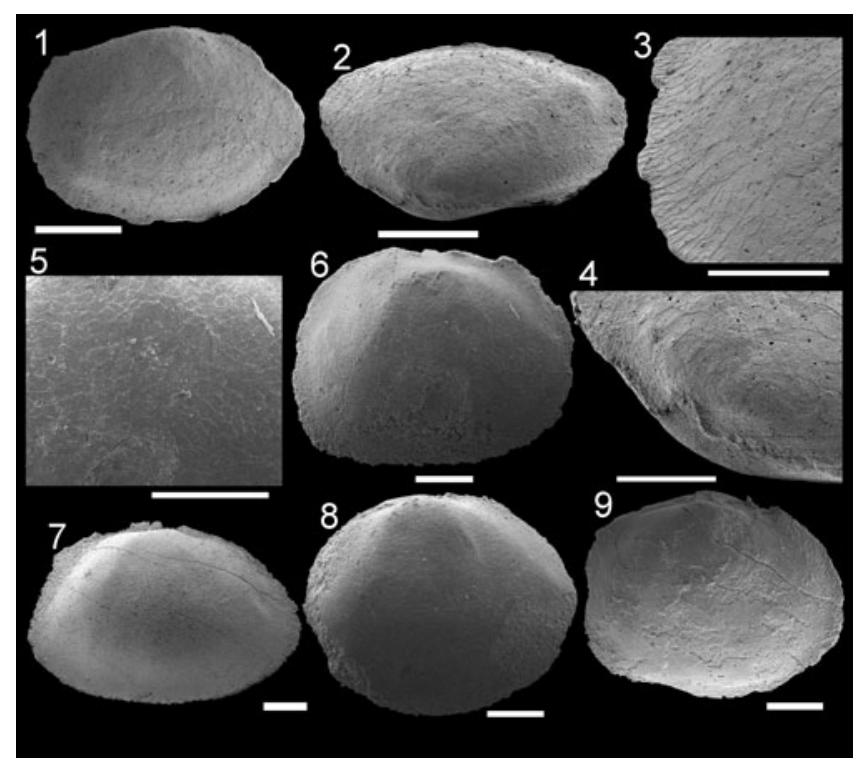

Figure 3. Pojetaia runnegari Jell, 1980 from the Shackleton Limestone. (1-4) Specimen SMNH Mo185039 in (1) lateral view, (2) dorsal view, (3) magnification of the central margin, showing laminar crystalline imprints, (4) magnification of the cardinal teeth shown in $(\mathbf{2})$. (5, 6) Specimen SMNH Mo185040, (5) lateral view, (6) magnification of lateral surface, showing laminar crystalline imprints. (7) Specimen SMNH Mo185041 in lateral view. (8) Specimen SMNH Mo185042 in lateral view. (9) Specimen SMNH Mo185043. (5, 6, 8) imaged under low vacuum settings. $(\mathbf{1}, \mathbf{2}, \mathbf{6 - 9})$ Scale bars $=200 \mu \mathrm{m}$; (3-5) scale bars $=100 \mu \mathrm{m}$.

Description.-Small equibivalved steinkerns, suboval or subcircular in outline to slightly extended caudally, range from $0.8-1.5 \mathrm{~mm}$ in length, $0.4-1.1 \mathrm{~mm}$ in height. Umbo central to subcentral and prosogyral. Shells $0.8-1.5 \mathrm{~mm}$ in length, 0.4 $1.1 \mathrm{~mm}$ in height. One to two cardinal teeth on straight dorsal hinge but sometimes not preserved. Small, projecting auricle present on posterior part of the hinge. Ventral margin slightly convex, transition to anterior and posterior margins variable from distinct bend to gentle curve. Ligament or muscle scars not preserved. Prismatic imprints present on the internal mold, covering the majority of the steinkern, becoming smaller but clearer at the ventral margin.

Materials.-Thirty-six steinkerns from localities HRSR 65, 68, HRSK 66, and HRA 2, 4, and 6 (Fig. 2)

Remarks.-Antarctic specimens are exclusively steinkerns, which hinders comparison to specimens preserved as external molds that are used to diagnose the species (e.g., Jell, 1980; Runnegar and Bentley, 1983; Runnegar in Bengtson et al., 1990; Skovsted, 2004; Elicki and Gürsu, 2009). The specimens fit within the known size and morphological range for P. runnegari (see Runnegar in Bengtson et al., 1990, figs. 165, 166; Parkhaev in Gravestock et al., 2001, p. 201-203, pl. 49, figs. 1-13, pl. 50, figs. 1-9; Elicki and Gürsu, 2009) and have a similar distribution of foliated aragonite imprints on the steinkern surface (Fig. 3.3, 3.5; cf. Runnegar and Bentley, 1983, fig. 6A, B, E, I; Bengtson et al., 1990, fig. 165E-G; Vendrasco et al., 2011, pl. 3, 4). Compared to measured specimens, height-to-length ratios and overall size of the Antarctic specimens cover the range of values for Pojetaia 
and Fordilla (Parkhaev in Gravestock et al., 2001, p. 202; Elicki and Gürsu, 2009, p. 275), although measurements given are few. The specimens are assigned to $P$. runnegari due to lack of visible muscle scars, typical for $P$. runnergari (Runnegar and Bentley, 1983) and shorter caudal extension than in Fordilla, a taxon not reported from East Gondwana.

Antarctic specimens are typically missing the anterior auricle, which appears to be broken off, although the posterior auricle is occasionally present (Fig. 3.7). Judging by the variation in caudal extension, the Antarctic specimens appear to conform to Jell's (1980) observation that the size of the posterior auricle is variable.

'Class Helcionelloida' Peel, 1991a

Order Helcionellida Geyer, 1994

Family Helcionellidae Wenz, 1938

Genus Davidonia Parkhaev, 2017b

Type species.-Davidonia davidi (Runnegar in Bengtson et al., 1990), by original designation (=Mellopegma rostratum Zhou and Xiao, 1984) from the lower Cambrian Parara Limestone, Stansbury Basin, South Australia, Dailyatia odyssei Zone.

Remarks.-Steinkerns of Davidonia exhibit a range of characteristics (Parkhaev in Gravestock et al., 2001, p.175) such as bilateral symmetry and presence of rugae (Parkhaev in Gravestock et al., 2001, p. 175-176) but typically preserve microstructural polygonal imprints of tabular aragonite on their surface (Vendrasco and Checa, 2015). Cyrtoconic Davidonia rostrata is typically more recurved than others (Fig. 4.6, 4.8, 4.6, 4.12; e.g., Parkhaev in Gravestock et al., 2001, pl. 40, figs. $1-3,5,8$, pl. 41, figs. 1, 2, 7, 8, 9). At the other end of the spectrum lies the erect, almost orthoconic Davidonia taconica (e.g., Landing and Bartowski, 1996, fig. 5.5, 5.7-5.9; Skovsted, 2004, fig. 3I, L). Davidonia taconica was originally included in the genus Stenotheca (Landing and Bartowski, 1996) but later removed and placed in a new genus 'Aequiconus' (Parkhaev in Gravestock et al., 2001). Skovsted (2004) later placed the species in Davidonia due to the prominent lateral rugae with polygonal aragonite imprints. This reassignment leaves $M$. taconica and another species, M. puppis Høyberget et al., 2015, from the Cambrian Stage 4 Evjevik Member of the Ringstrand Formation Norway (Høyberget et al., 2015), as outliers within the genus, as they lack a parietal train.

\section{Davidonia rostrata (Zhou and Xiao, 1984)}

Figure 4.6-4.14

1984 Mellopegma rostratum n. sp. Zhou and Xiao, p. 132, pl. 3 , figs. $7-10$.
?1984 Bemella anhuiensis n. sp. Zhou and Xiao, p. 129, pl. 1, figs. 8, 9.

?1984 Bemella costa n. sp. Zhou and Xiao, p. 128, pl. 1, fig. 10.

1990 Mackinnonia davidi n. sp. Runnegar in Bengtson et al., p. 234, figs. $159,160 \mathrm{~J}$.

1994 Mellopegma rostratum; Feng et al., p. 7, pl. 2, figs. 5-9.

1996 Mackinnonia obliqua n. sp. Landing and Bartowski, p. 754, figs. 5.10-5.16.

2001 Mackinnonia rostrata; Parkhaev in Gravestock et al., p. 176, pl. 40, 41.

?2002 Mackinnonia obliqua; Landing et al., p. 296, fig. 8.3.

2004 Mackinnonia rostrata; Skovsted, p. 16, fig. 3A-H.

?2006 Mackinnonia cf. M. rostrata; Wotte, p. 151, fig. 5 g-k.

2014 Mackinnonia rostrata; Parkhaev, p. 374, pl. 3, figs. 2, 3.

2016 Mackinnonia sp.; Jacquet and Brock, p. 340, fig. 5 H, J.

2016a Mackinnonia rostrata; Betts et al., p. 196, fig. 18N-U.

Holotype.-No. 800059, Geological Institute, Anhui Province, People's Republic of China. Internal mold from the Xinji (=Yutaishan) Formation of the lower Cambrian of Anhui Province, China.

Occurrence.-Cambrian, Stage 2 and Series 2, Stages 3-4 Dailyatia odyssei Zone of South Australia, Cambrian Series 2 Stages 3-4 of North China, Northeast Greenland, Taconic Allochthon of New York, USA, Quebec, Canada, and East Antarctica. Potentially Cambrian Stage 5 of northwestern Spain.

Description.-Moderately high, cyrtoconic steinkerns, coiled through one-third of a whorl and moderately laterally compressed. Range $0.5-1.3 \mathrm{~mm}$ in length, $0.2-0.8 \mathrm{~mm}$ in height (see Table 1), and approximately 1.5 times longer than high. Protoconch reclined, rounded, rapidly expanding, and distinct from the teleoconch by change in microstructural imprints from smooth to polygonal. Strongly hooked apex directly above the parietal train or displaced up to one-quarter the length of the steinkern beyond the parietal train. Supra-apical field evenly convex, subapical field short and concave; moderate rate of expansion. Apertural outline elongated elliptical, sometimes with short rounded parietal train separated by a distinct indent from the subapical field. Rounded parietal train tilts upward at an angle. In lateral view the aperture exhibits a convex profile. Transverse rugae subdued, not present on all Antarctic material but terminate before subapical field when present. Some small juvenile specimens lack rugae. Polygonal microstructural imprints (9-12 $\mu \mathrm{m}$ wide) are exhibited on the surface of the co-marginal rugae, with

\footnotetext{
Figure 4. Helcionellids from the Shackleton Limestone. (1-5) Davidonia cf. D. corrugata Runnegar in Bengtson et al., 1990. (1-3) Specimen SMNH Mo185044 in (1) oblique lateral view, (2) apical view, (3) magnification of apical region in lateral view, showing protoconch and transition to teleoconch; (4) specimen SMNH Mo185045, oblique view of supra-apical field; (5) specimen SMNH Mo185046 lateral view. (6-14) Davidonia rostrata (Zhou and Xiao, 1984), (6, 7) specimen SMNH Mo185047, (6) lateral view, (7) dorsal view of supra-apical field; (8-11) specimen SMNH Mo185048, (8) magnification of lateral view of parietal train, showing polygonal crystalline imprints on the side surface, (9) dorsal view of supra-apical field, (10) lateral view, (11) magnification of oblique lateral view of supra-apical field, showing polygonal crystalline imprints; (12) specimen SMNH Mo182501 in lateral view; (13) specimen SMNH Mo182502 in lateral view; (14) specimen SMNH Mo182503 in lateral view. (15-18) Xianfengella cf. X. yatesi Parkhaev in Gravestock et al., 2001, specimen SMNH Mo185049, (15) dorsal view, (16) oblique apical view, (17) magnified view of supra-apical field showing crystalline imprints, (18) oblique lateral view. (19-21) Protowenella? sp. Runnegar and Jell, 1976 specimen SMNH Mo185050, (19) lateral view, (20) dorsal view, (21) apical view. (22-28) Anuliconus sp. Parkhaev in Gravestock et al. (2001), (22-24) specimen SMNH Mo185051, (23) lateral view, (22) magnification of apex in lateral view, (24) apertural view; (25, 26) specimen SMNH Mo185052, (25) lateral view, (26) apical view; $(\mathbf{2 7}, \mathbf{2 8})$ specimen SMNH Mo185053, (27) lateral view, $(\mathbf{2 8})$ apical view. $(\mathbf{3}, \mathbf{1 0}, \mathbf{1 1}, \mathbf{1 7}, \mathbf{2 2}, \mathbf{2 4}) \mathrm{Scale}$ bars $=100 \mu \mathrm{m}$; all others, scale bars $=200 \mu \mathrm{m}$.
} 


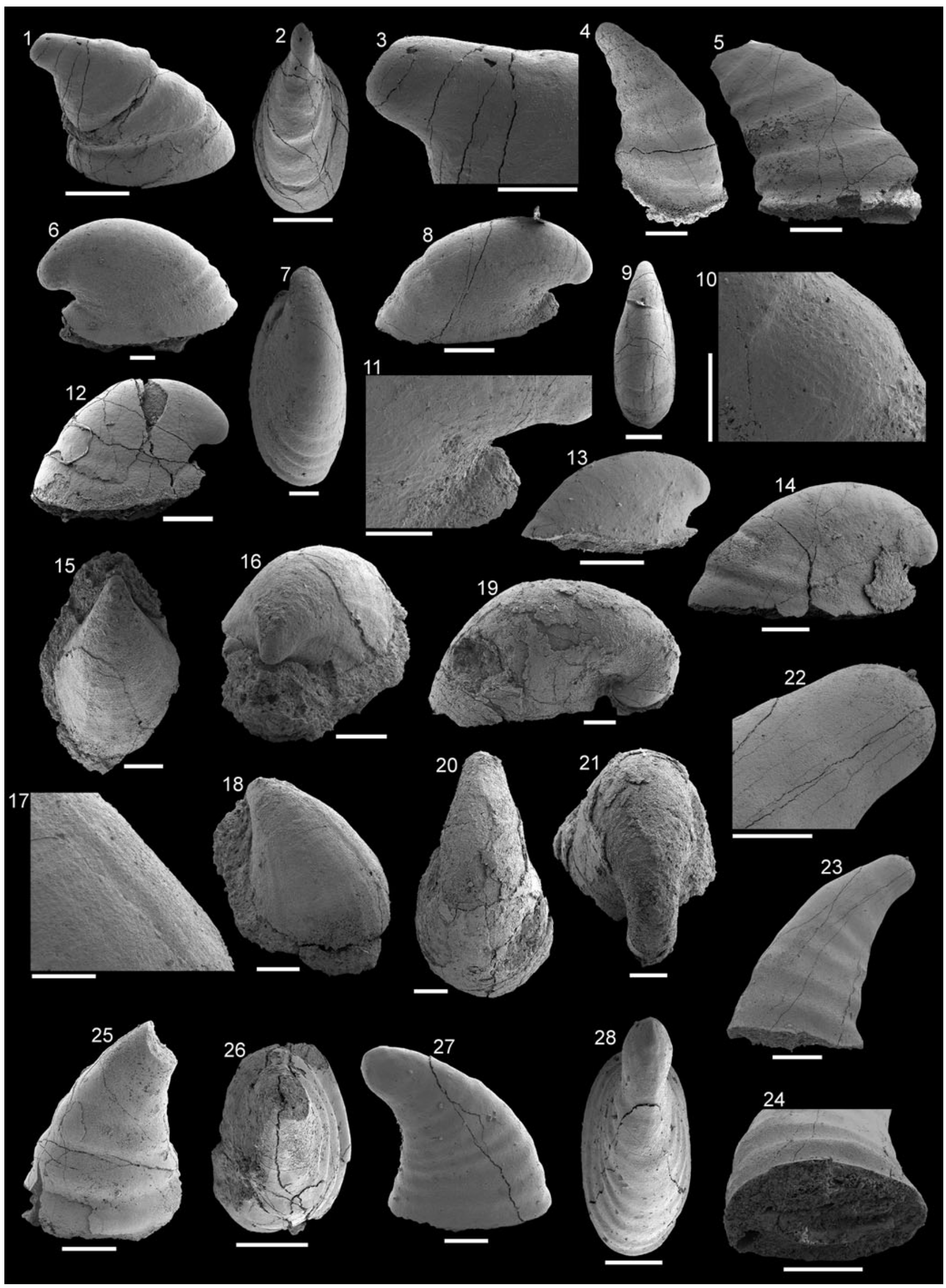


Table 1. Height and length measurements of selected specimens of Davidonia rostrata (Zhou and Xiao, 1984).

\begin{tabular}{lccl}
\hline Specimen ref. & Length $(\mu \mathrm{m})$ & Height $(\mu \mathrm{m})$ & L/H ratio \\
\hline HRA2-POSt01-Sa02 & 745 & 428 & 1.740654 \\
HRA2-POSt01-Sa05 & 1,053 & 596 & 1.766779 \\
HRA2-POSt01-Sa06 & 658 & 381 & 1.727034 \\
HRA4-POSt01-Sa03 & 1,083 & 869 & 1.24626 \\
HRA4-POSt01-Sa04 & 576 & 359 & 1.604457 \\
HRA6-POSt01-Sa02 & 827 & 488 & 1.694672 \\
HRA6-POSt01-Sa04 & 788 & 497 & 1.585513 \\
HRA6-POSt01-Sa08 & 748 & 472 & 1.584746 \\
HRA6-POSt01-Sa14 & 581 & 367 & 1.583106 \\
HRA6-POSt01-Sa15 & 699 & 494 & 1.41498 \\
HRA6-POSt01-Sa17 & 513 & 245 & 2.093878 \\
HRA6-POSt02-Sa02 & 650 & 338 & 1.923077 \\
HRA6-POSt02-Sa05 & 623 & 349 & 1.7851 \\
HRA6-POSt02-Sa07 & 928 & 586 & 1.583618 \\
HRA6-POSt02-Sa08 & 703 & 515 & 1.365049 \\
HRA6-POSt02-Sa09 & 582 & 382 & 1.52356 \\
HRA6-POSt02-Sa12 & 963 & 558 & 1.725806 \\
HRA6-POSt02-Sa13 & 726 & 419 & 1.732697 \\
HRA6-POSt02-Sa15 & 777 & 515 & 1.508738 \\
HRA6-POSt02-Sa18 & 550 & 320 & 1.71875 \\
HRA6-POSt02-Sa19 & 1,328 & 843 & 1.575326 \\
\hline
\end{tabular}

smooth furrows. The parietal train has pitted depressions on the steinkern surface (3-5 $\mu \mathrm{m}$ wide), and the protoconchs are smooth.

Materials. - ca. 100 steinkerns of varying size and quality of preservation from HRA 2, 4-6.

Remarks.- Specimens identified as Davidonia rostrata from the Shackleton Limestone range in size and shape (see Table 1), lending support to the concept that this is a morphologically variable species (Parkhaev in Gravestock et al., 2001). This morphological variation is interpreted to reflect ontogenetic, taphonomic, and potential intraspecific variation in this taxon group. Significant variation in the shape of the protoconch between biogeographically distinct assemblages of this species indicate they were morphologically distinct from an early ontogenetic stage, although qualitatively identical at later stages (Jackson and Claybourn, 2018). Smaller specimens (e.g., Fig. 4.13: $\sim 0.6 \mathrm{~mm}$ in length, $0.3 \mathrm{~mm}$ in height) resemble a similarly recurved helcionellid, Figurina nana (Zhou and Xiao, 1984), which can otherwise be readily distinguished from $D$. rostrata by the lack of distinct rugae, a transverse depression above the aperture, and circular protoconch. Some of the specimens (e.g., Fig. 4.13) from the Shackleton Limestone where the rugae are absent are considered juveniles of $D$. rostrata due to their smaller size compared to figured specimens of $F$. nana (Zhou and Xiao, 1984, pl. 3, fig. 11a; Parkhaev in Gravestock et al., 2001, pl. 35 , figs. 4-8) and shared microstructure with other D. rostrata specimens from the Shackleton Limestone (Fig. 4.10, 4.11). A similar pattern was recognized among Australian specimens by Parkhaev in Gravestock et al. (2001, pl. 41, fig. 11).

Figured specimens of Davidonia rostrata from the Xinji Formation of the North China platform (Zhou and Xiao, 1984, pl. 1, figs. 8-10, pl. 2, figs. 1-10; Feng et al., 1994 pl. 2, figs. 5-8) are typically tall, strongly recurved examples of Davidonia rostrata with prominent rugae and with weakly developed parietal trains. Exceptions are two specimens figured by Zhou and Xiao (1984, pl. 1, figs. 8, 9), which are longer than high, are more recurved, and lack parietal trains. The loss of the train is probably due to an incomplete formation of the steinkern, as the rugae are truncated at the base. This morphological variability in height is also reflected in Antarctic specimens, with moderate (Fig. 4.6, 4.12) and low specimens (Fig. 4.8, 4.14) occurring together, but with identical rugae, microstructural imprints, and parietal train.

A wide range of morphologies is figured in Gravestock et al. (2001, pl. 40, 41) from the Parara Limestone (Stansbury Basin, Cambrian Series 2, Stages 3-4), Sellick Hill Formation (Stansbury Basin, Terreneuvian, Stage 2), and the Mernmerna Formation (Arrowie Basin, Cambrian Series 2, Stages 3-4), South Australia. Larger specimens have more prominent rugae than those from the Shackleton Limestone (Gravestock et al., 2001, pl. 40 , figs. $1-3,5 a, 8$, pl. 40 , figs. $1-7,9$ ), and smaller specimens tend to lack (Gravestock et al., 2001, pl. 41, fig. 11) or have subdued rugae (Gravestock et al., 2001, pl. 41, figs. 6, 10). This probably reflects the ontogeny of Davidonia rostrata, with shell thickenings (preserved as rugae observed on steinkerns) only developing later in their ontogeny. This distribution is comparable to some smaller D. rostrata specimens (Fig. 4.13). Another feature that only appears to occur on larger specimens is the development of a sinus on the parietal train (Gravestock et al., 2001, pl. 40, figs. 4, 6). Compared to specimens from the Shackleton Limestone, Australian specimens generally have a larger maximum size, with more prominent rugae, but share the same strong recurvature and microstructure. Runnegar in Bengtson et al. (1990) figured specimens (fig. 159 A$\mathrm{H})$ from the Parara Limestone and the upper part of the Ajax Limestone (Cambrian Series 2, Stages 3-4), also in South Australia. These share a common morphology with other specimens figured in Gravestock et al. (2001), as well as having a transverse thickening on the subapical field (Runnegar in Bengtson et al., 1990, fig. 159A, B), a feature that is lacking in Antarctic specimens.

Skovsted (2004, fig. 3A, B, F) described Davidonia rostrata from the Bastion Formation (unnamed Cambrian Series 2, Stages 3-4) of northeast Greenland, which consists of specimens with lower profiles, more subdued rugae, and parietal trains that lack sinuses (Skovsted, 2004, fig. 3G, C). Both characteristics are more similar to specimens from the Shackleton limestone (e.g., Fig. 4.6, 4.8, 4.14,). Included in Skovsted's (2004) synonymy of Davidonia rostrata was 'Mackinnonia sp.' (Kouchinsky, 2000, fig. 10) from Siberia, which was reassigned to Davidonia anabarica Parkhaev, 2005. Although similar to D. rostrata in its overall morphology, the steinkerns of D. anabarica show prominent transverse tubercles, clearly distinguishing it from D. rostrata (Kouchinsky, 2000, fig. 10 E; Parkhaev, 2005, pl. 2, fig. 2E).

'Mackinnonia cf. M. rostrata' from the Leonian (Cambrian Stage 5) Láncara Formation of northern Spain (Wotte, 2006) is only tentatively included in the synonymy list, due to the poor preservation and younger stratigraphic age compared to D. rostrata sensu stricto. The synonymization by Parkhaev (in Gravestock et al., 2001) of Bemella anhuiensis Zhou and Xiao 1984 and B. costa with Davidonia rostrata have been followed here, but with some uncertainty due to the low clarity of the images available from the original descriptions by Zhou and Xiao (1984). Kouchinsky et al. (2015, p. 430) expressed 
doubt in the synonymy of Davidonia davidi with $D$. rostrata due to $D$. davidi having a higher profile, greater degree of coiling, and more-prominent rugae on the steinkerns. Material from the Shackleton Limestone have examples that have both moderate profiles and subdued rugae (Fig. 4.6, 4.12), indicating these characteristics alone are not sufficient to distinguish the two species. This leaves the prominence of rugae alone to distinguish the two, which might be ontogenetic, ecophenotypic, or influenced by taphonomic processes of replication of the shell and shell interior of micromollusks by calcium phosphate (Creveling et al., 2014).

Davidonia cf. D. corrugata (Runnegar in Bengtson et al., 1990) Figure 4.1-4.5

See Supplementary file 1 for taxa assigned to Davidonia corrugata

Holotype.-'Lepostega? corrugata' Runnegar in Bengtson et al., 1990, SAMP29006, Cambrian Stage 3 Parara Limestone, Carramulka, South Australia.

Occurrences.—Davidonia corrugata occurs in the Cambrian Stages 3-4 Dailyatia odyssei Zone in South Australia.

Description.-High cyrtoconic, erect steinkerns with hooked apex, moderately laterally compressed, apex displaced beyond subapical margin. Steinkerns $0.5-0.6 \mathrm{~mm}$ in length and $0.5-$ $0.6 \mathrm{~mm}$ in height. Protoconch smooth, small, and pinched, distinct from teleoconch, which expands more rapidly. Supra-apical field convex, subapical field gently concave, moderate rate of expansion. Aperture elliptical to subquadrate. Transverse rugae broad, flat, and subrectangular in profile with reduced width of furrows. Rugae encircle the teleoconch and preserve surficial polygonal imprints, which extend to the uppermost parts of the furrows. Lower parts of the furrows and protoconch are smooth. Parietal train not present in any recovered specimens.

Materials.—Five steinkerns from locality HRA6.

Remarks.-Davidonia corrugata was synonymized with Davidonia plicata (=Isitella plicata Missarzhevsky, 1989) without detailed explanation (Parkhaev in Gravestock et al., 2001, p. 178) and only a brief discussion in a later publication (Parkhaev 2005, p. 618). We follow Skovsted (2004, p. 15) and refer the specimens to Davidonia cf. D. corrugata (Runnegar in Bengtson et al., 1990).

Compared to specimens of Davidonia rostrata from the Shackleton Limestone, these specimens are far less recurved and have more prominent rugae. The lack of a parietal train and less recurved form are similar to $D$. taconica from Northeast Greenland (Skovsted, 2004, p. 17-18, figs. 3I-R, 4), but the greater recurvature and more prominent rugae are sufficient to distinguish the two. Davidonia puppis Høyberget et al., 2015 is similar to Davidonia cf. D. corrugata but is much larger in size, up to $6.5 \mathrm{~mm}$ in length (Høyberget et al., 2015, p. 49), and has a less recurved apex (Høyberget et al., 2015, fig. 16, A-J).
Specimens from South Australia show different rates of expansion from the apex: from rapidly expanding with a short protoconch (Runnegar in Bengtson, 1990, p. 237, fig. 160AG; Parkhaev in Gravestock et al., 2001, p. 296, pl. 39, figs. 612) to morphologies with a narrow, elongate protoconch (Topper et al., 2009, p. 226, fig. 9A-H). The specimens are referred to Davidonia cf. D. corrugata due to their broad, prominent rugae (Fig. 4.5) and upright suborthoconic profile (Fig. 4.1, 4.4, 4.5), which are most similar to those figured by Topper et al. (2009, fig. 9A-H). A more certain assignment to a species is precluded by lack of information on the aperture and low number of specimens. The broad rugae, narrow furrows, and high profile also differentiate the specimens from Davidonia rostrata, which is characterized by narrower and less prominent rugae and a protoconch that is broader and more rounded. Davidonia taconica can also be readily distinguished from $D$. cf. $D$. corrugata by having a more upright form, broader protoconch, and reduced bilateral compression (cf. Skovsted, 2004, fig. 3I-R). The specimens of $D$. corrugata from the Mermerna Formation, South Australia, have the same pinched protoconch as the Shackleton Limestone specimens (cf. Fig. 4.1-4.3 with Topper et al., 2009, pl. 9, fig. H), while specimens from the Parara Limestone (Stansbury Basin) and Oraparinna Shale (Arrowie Basin) have broad, more spoon-shaped protoconchs in outline, leading to a more regular rate of whorl expansion (Runnegar in Bengtson et al., 1990, fig. 160A-F; Gravestock et al., 2001, pl. 39, figs. 4, 6b). The Shackleton Limestone specimens also lack a parietal train, unlike specimens from South Australia (Gravestock et al., 2001, pl. 38, fig. 7, pl. 39, figs. $2,3,7$ ), although this is likely taphonomic due to incomplete steinkern formation.

Genus Xianfengella He and Yang, 1982

Type species.-Xianfengella prima $\mathrm{He}$ and Yang, 1982 by original designation, from the lower Cambrian Zhongyicun Member of the Meishucun Formation, Yunnan Province, China.

Xianfengella cf. X. yatesi Parkhaev in Gravestock et al., 2001 Figure 4.15-4.18

See Supplementary file 1 for taxa assigned to Xianfengella yatesi.

Holotype.-PIN 4664/1506, Paleontological Institute, Russian Academy of Sciences, Moscow, Russia. Steinkern from the Parara Limestone, Horse Gully, Yorke Peninsula, South Australia, Dailyatia odyssei Zone.

Occurrence.-Xianfengella yatesi is known from Cambrian Stages 3-4 Dailyatia odyssei Zone of South Australia. Possibly known from Northeast Greenland and East Antarctica.

Description.-Low, cap-shaped steinkern, recurved to approximately one-third of a whorl, apex recurved, displaced beyond the aperture. Single specimen approximately $0.6 \mathrm{~mm}$ wide, $0.6 \mathrm{~mm}$ high, and $0.9 \mathrm{~mm}$ long: two-thirds as wide as it is long. Apex narrow, expands rapidly after first $200 \mu \mathrm{m}$, with no distinction between protoconch and teleoconch. Lateral fields and supra-apical field strongly convex. Subapical field 
short and concave with pegma-like brim at base. Ovoid apertural outline, tapered to the apex, rounded to the base of the supra-apical field. Radial rugae extend from near the apex to the aperture. Polygonal imprints present on entire steinkern surface $13-18 \mu \mathrm{m}$ wide.

Materials._-Single well-preserved steinkern from HRA 4.

Remarks.-Xianfengella has been included within the helcionelloids despite previous comparisons to the cap-like terminations in halkieriids as well as Ocruranus-like fossils (Peel and Skovsted, 2005). The polygonal imprints on the steinkern of this specimen (Fig. 4.17) resemble the polygonal aragonite imprints found on other helcionelloids (e.g., Vendrasco et al., 2010, p. 1, figs. 4, 5; Vendrasco and Checa, 2015, figs. 2A-D) rather than the layered fibrous bundles that characterize Ocruranus (Vendrasco et al., 2009, pl. 1). The Antarctic specimens differ from those figured from South Australia (Gravestock et al., 2001, pl. 34). Diamond-shaped depressions and smooth ridges were reported, but not clearly figured, on the surfaces of the South Australian steinkerns (Parkhaev in Gravestock et al., 2001), which may correspond to the polygonal imprints and longitudinal ridges on the Antarctic specimen. Other features are more easily compared, such as a notch at the subapical margin of the aperture (compare Fig. 4.16 with Gravestock et al., 2001, pl. 34. figs. 6b, 8a, 8b; Topper et al., 2009, fig. 10J) and strongly recurved and posteriorly displaced apex (Fig. 4.16, 4.18; Gravestock et al., 2001, pl. 34, figs. 1, 6a, 8b; Topper et al., 2009, fig. 10J). Unfortunately, the aperture and some of the subapical field are both obscured by clastic material in this specimen, making this feature difficult to decipher for closer comparison to X. yatesi from South Australia.

The specimen appears most similar to Xianfengella? cf. $X$. yatesi from the Bastion Formation, Northeast Greenland (Peel and Skovsted, 2005) in terms of the polygonal microstructure on the steinkern exterior (Peel and Skovsted, 2005, fig. 5P) and radial ridges (fig. $5 \mathrm{~F}$ ). Both the Antarctic and Northeast Greenland specimens preserve a brim at the subapical part of the aperture (Fig. 4.16; Peel and Skovsted, 2005, fig. 5A-G, J), which is not present on South Australian specimens (cf. short parietal train of Parkhaev in Gravestock et al., 2001, pl. 34, figs. 1, 2, 8a). For this reason and the fact that only a single specimen has been recovered from the Shackleton Limestone, a cautious taxonomic approach is taken, and we refer this specimen to Xianfengella $\mathrm{cf}$. X. yatesi.

Genus Anuliconus Parkhaev in Gravestock et al., 2001

Type species.-Anuliconus magnificus, Parkhaev in Gravestock et al., 2001 by original designation from Kulpara Formation (Cambrian Stages 2-3) and Parara Limestone (Cambrian Stages $3-4)$ in the Stansbury Basin and Mernmerna Formation (Cambrian Stages 3-4) in the Arrowie Basin, South Australia.

\section{Anuliconus sp.}

Figure 4.22-4.28

Description.-High cyrtoconic and moderately bilaterally compressed steinkerns with lateral fields concave at the apex transitioning to flat on the teleoconch. Apex gently recurved over subapical field. Specimens approximately $0.4-0.5 \mathrm{~mm}$ wide, $0.5-0.7 \mathrm{~mm}$ long, and $0.7-0.9 \mathrm{~mm}$ high. Protoconch elongated to knob-like, separated from the teleoconch by a distinct pinching. Supra-apical surface gently convex, subapical surface moderately concave, low to moderate rate of expansion. Apertural outline varies from elliptical to subcircular. Regular, rounded, concentric rugae encircle teleoconch.

Materials.-Thirty-three steinkerns from HRSK 66, HRA 2, 6.

Remarks.-The Antarctic specimens generally fall within the documented intraspecific variation of the genus based on the original description of Anuliconus (Parkhaev in Gravestock et al., 2001, p. 142, pl. 25, figs. 8-17). The steinkerns are moderately bilaterally compressed, gently recurved with a concave subapical field and a convex supra-apical field, with a displacement of the apex over the subapical field and concentric rugae. It is possible the specimens from the Shackleton Limestone represent more than one species due to variations in these features, such as having more subdued (Fig. 4.27) to more prominent (Fig. 4.23, 4.24) rugae and a more (Fig. 4.27) or less (Fig. 4.23) concave subapical field, but these differences alone are insufficient for species distinction. Most of the collection have irregular apertural outlines (Fig. 4.26) or rugae truncated at the aperture (Fig. 4.23, 4.24, 4.25), indicating incomplete steinkerns ('teilsteinkerns' sensu Dattilo et al., 2016). Anuliconus sp. are easily distinguished from the similarly shaped Obtusoconus $\mathrm{Yu}, 1979$ by having a protoconch recurving over the subapical field.

Parkhaev in Gravestock et al., (2001) named three new species from Cambrian Series 2 sediments of South Australia, of which Anuliconus magnificus Parkhaev in Gravestock et al., (2001, p. 141) and Anuliconus truncatus Parkhaev in Gravestock et al. (2001, p. 144) bear some similarities to specimens from the Shackleton Limestone. Anuliconus magnificus shares a similar profile to taller Antarctic specimens (compare Fig. 4.23 with Gravestock et al., 2001, pl. 24, figs. 8-17) and rounded triangular ribs (Fig. 4.25), and the more irregular, subdued ribs on some specimens (Fig. 4.27, Gravestock et al., 2001, pl. 25, figs. 8-15) are similar to A. truncatus (Gravestock et al., 2001, pl. 26, fig. 1-4).

\section{Genus Protowenella Runnegar and Jell, 1976}

Type species.-Protowenella flemingi Runnegar and Jell, 1976 by original designation from the Cambrian Series 5 Currant Bush Limestone, Locality L128, Queensland, Australia.

\section{Protowenella? sp.}

Figure 4.19-4.21

Description.-Planispiral, open-coiled steinkern coiling through three-quarters of a whorl, apex displaced beyond subcircular apertural margin. Height $\sim 0.9 \mathrm{~mm}$ and total length $\sim 1.5 \mathrm{~mm}$. Protoconch slender and elongate with no clear distinction from the teleoconch. Supra-apical field strongly convex; shell exhibits gradual expansion to half a whorl, followed by more rapid expansion of the rest of the 
teleoconch. Aperture outline subcircular to ovoid, tapering toward apex. Sinus or umbilicus absent.

Materials.—Four poorly preserved steinkerns from HRA 2, 5, 6.

Remarks. - These globose planispiral steinkerns recovered from the Shackleton Limestone are included in the genus Protowenella, but only tentatively due to their poor preservation and low number. The specimens from the Shackleton Limestone have the general morphological features of the genus, such as planispiral, involute profile (Fig. 4.194.21), overall globose appearance, and they lack an apertural sinus (Runnegar and Jell, 1976, p. 133). The specimens do not have the important circumbilical channels figured but not included in the original diagnosis (Runnegar and Jell, 1976, fig. 6E; see also Brock, 1998) and described in the revised diagnosis (Berg-Madsen and Peel, 1978, p. 118). The Antarctic specimens are more tightly coiled (Fig. 4.19) than Protowenella cobbensis Mackinnon, 1985 (fig. 9G), so they can be more closely compared to the more openly coiled type species Protowenella flemingi Runnegar and Jell, 1976 (fig. 6). The only other Cambrian Series 2 species that have been described are from the Xinji Formation of South China: Protowenella primaria Zhou and Xiao, 1984 and Protowenella huainanensis Zhou and Xiao, 1984. P. primaria figured from the Xinji Formation is typically planispiral, but some specimens might demonstrate slight asymmetry (e.g., Zhou and Xiao, 1984, pl. 3, fig. 19a, b, pl. 4, figs. 4b, 5b). They also do not coil as tightly as the Shackleton Limestone specimens, and they have a broad umbilicus. This asymmetry seems to be more pronounced in P. huiananensis (Zhou and Xiao, 1984, pl. 3, figs. 18b, 19b). These specimens also appear to lack circumbilical channels (Zhou and Xiao, pl. 3, figs. 18-20, pl. 4, figs. 1-5). The lack of circumbilical channels in specimens described as Protowenella indicate they may not have the necessary features to be included in the genus (Berg-Madsen and Peel, 1978), an issue discussed by Brock (1998), who pointed out another species, P. plena Missarzhevsky and Mambetov, 1981, may also be excluded on the same basis. The only specimen of Protowenella that can be confidently assigned to the genus from Cambrian Series 2 rocks is Protowenella sp. from the Cambrian Series 2, Stage 4, Tempe Formation from the Northern Territory, Australia, on the basis of well-preserved muscle scars (Smith et al., 2015, fig. 6H).

With these factors in mind, the specimens from the Shackleton Limestone have only been tentatively included in Protowenella, with the caveat that if better-preserved specimens are discovered that entirely lack circumbilical channels, they should be removed from the genus (Brock, 1998). A full redescription of all Protowenella specimens is necessary to resolve these problems. The degree of expansion and elongation of the apex is similar to figured specimens of Protowenella sp. from the middle Cambrian of Siberia (Gubanov et al., 2004, fig. 10). Another planispiral, Protowenella-like univalved mollusk from Shackleton Limestone has been figured but not described (Rowell et al., 1988b, pl. 1, figs. O, P) and is referred to only as a 'euomphalid mollusk.'
Family Yochelcionellidae Runnegar and Jell, 1976 Genus Yochelcionella Runnegar and Pojeta, 1974

Type species.-Yochelcionella cyrano Runnegar and Pojeta, 1974 by original designation, Cambrian Series 3, "first discovery limestone' Member of the Coonigan Formation, New South Wales, Australia.

\section{Yochelcionella sp. \\ Figure 6.1-6.8}

Description.-Cyrtoconic, moderately bilaterally compressed steinkerns with cylindrical subapical extension or cross section of shell forming a snorkel. Apex positioned above commencement of snorkel in lateral view. Protoconch rounded with distinctive pinching marking transition between protoconch and teleoconch; one specimen with faint polygonal imprints (Fig. 2). Subapical field short and concave, supra-apical field evenly convex. Elongate oval aperture broken in both specimens. Faint transverse rugae present between protoconch and snorkel. Irregular pitted microstructural imprints in surface of the teleoconch steinkern, $2-5 \mu \mathrm{m}$ wide.

Materials.-Five steinkerns from HRSK 66, HRSR 68, and HRA 2.

Remarks. - Although the specimens are damaged, they appear most similar to Yochelcionella chinensis Pei, 1985 as both specimens show displacement of the apical part of the shell above the snorkel away from the subapical field (Pei, 1985, fig. 1a). Specimens from the Shackleton Limestone have rounded, rapidly expanding protoconchs with a distinctive pinch at the transition to the teleoconch (Fig. 6.1, 6.2). The specimens can be distinguished from $Y$. gracilis Atkins and Peel, 2004 from the Henson Gletscher Formation (Cambrian Stages 2-3) of North Greenland by their convex supra-apical field, where $Y$. gracilis has a concave supra-apical field (Atkins and Peel, 2004, fig. 3A, F). Yochelcionella greenlandica Atkins and Peel, 2004 from the Aftenstjernes $\varnothing$ Formation (Cambrian Stage 2) of North Greenland has a similar displacement in the subapical field below the snorkel (Atkins and Peel, 2004, fig. 2B, D, L, N) but has well-developed rugae, which are fewer in number and much larger than Yochelcionella sp. from the Shackleton Limestone (Fig. 6.2, 6.5-6.8; see Atkins and Peel, 2004, fig. 2A, F, J). Specimens of $Y$. crassa Esakova and Zhegallo, 1996 from the Bystraya Formation (Siberian Botoman Stage), Eastern Transbaikalia, figured by Parkhaev (2014, pl. 1, figs. 15-18), show a similar strongly concave subapical field and highly reduced rugae, but the Shackleton Limestone specimens are not well preserved enough to draw closer comparisons. The rounded protoconch, pinching, fine rugae, and displacement are also present in Yochelcionella cf. Y. chinensis from the Forteau Formation (Cambrian Series 2, Stages 3-4), Newfoundland (Skovsted and Peel, 2007, fig. 4D). Specimens preserve a pitted microstructure on the steinkern exteriors of the teleoconchs (Fig. 6.5, 6.6). Microstructure preserved on 


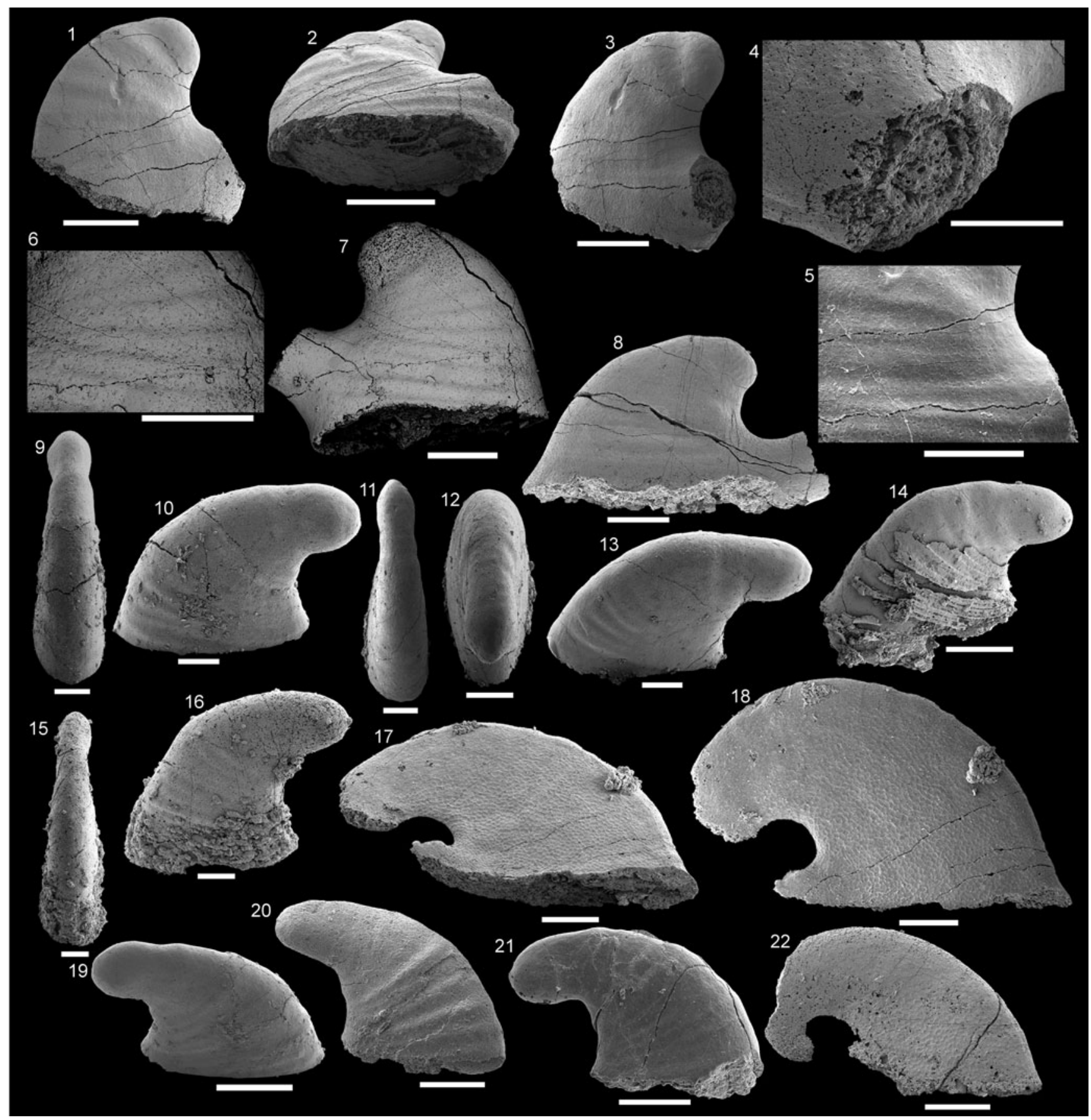

Figure 5. Yochelcionella sp., Stenotheca sp., and Anabarella cf. A. australis Runnegar in Bengtson et al., 1990 from the Shackleton Limestone. (1-8) Yochelcionella sp., (1-5) specimen SMNH Mo185063, (1) lateral view, (2) apertural view, (3) apical view of subapical field and broken snorkel, (4) magnified view of concentric structures within snorkel, (5) magnified view of pitted microstructure; (6, 7) specimen SMNH Mo185064, (6) magnification of lateral view, (7) lateral view; (8) specimen SMNH Mo185065, lateral view. (9-16, 19-21) Stenotheca sp. (9, 10) specimen SMNH Mo185066, (9) oblique lateral view, (10) dorsal view; (11-13) specimen SMNH Mo185067, (11) oblique lateral view, (12) dorsal view of subapical field, (13) apical view; (14) specimen SMNH Mo185068, lateral view; (15, 16) specimen SMNH Mo185069, (15) oblique lateral view, (16) dorsal view; (19) specimen SMNH Mo185071 in lateral view; (20) specimen SMNH Mo185072 lateral view; (21) specimen SMNH Mo185073 lateral view; (17, 18, 22) Anabarella cf. A. australis $(\mathbf{1 7}, \mathbf{1 8})$ specimen SMNH Mo185070 in $(\mathbf{1 8})$ lateral view, (17) apertural view (22) specimen SMNH Mo185074 in lateral view. Scale bars $100 \mu \mathrm{m} \mathrm{(5,6)}$ all others $200 \mu \mathrm{m}$. All images taken using secondary electrons except (5) taken in low vacuum mode and $(\mathbf{6}, 7)$ taken using backscattered electrons.

steinkerns of Yochelcionella has been reported previously. Vendrasco et al. (2010) described laminar and polygonal microstructures (pl. 6) on Y. saginata Vendrasco et al., 2010 and $Y$. snorkorum Vendrasco et al., 2010, inverted relative to those seen on other micromullusks (i.e., the polygon is raised and the walls between them are depressed) from the Drumian Gowers Formation from the Geogina Basin in Queensland, Australia. Kouchinsky (2000) described Yochelcionella sp. from the lower Cambrian of Siberia that preserved both polygons (with normal relief) and tubercles at the apex 
(Kouchinsky, 2000, fig. 9). These five microstructural types, laminar, inverted polygons, normal polygons, tubercles, and now pits, on a single genus of helcionelloid represents a wide range of strategies for biomineralization.

Wrona (2003) reported a single specimen of Yochelcionella? sp. from glacial erratics of King George Island, West Antarctica. The specimen is poorly preserved, with no information on the teleoconch below the snorkel (Wrona, 2003, fig. 13 $\mathrm{A}_{1}$ ). The apex has a similar rounded shape to the Shackleton Limestone specimens (Fig. 6.1, 6.7, 6.8; Wrona, 2003, fig. 13A $\mathrm{A}_{1}$ ).

\section{Family Stenothecidae Runnegar and Jell, 1980 Genus Stenotheca Hicks, 1872}

Type species.-Stenotheca cornucopia Salter in Hicks, 1872 by original designation, lower Cambrian, Pembrokeshire, Wales. The type specimen was reported lost while on loan from the Sedgwick Museum, Cambridge (Runnegar in Bengtson et al., 1990).

\section{Stenotheca $\mathrm{sp}$.}

Figure 6.9-6.16, 6.19-6.21

Description.-Bilaterally compressed steinkern, coiled to one-quarter of a whorl. Hooked apex, with entire protoconch displaced beyond subapical margin. Apertural length 0.3$0.5 \mathrm{~mm}$, total height $0.35-0.55 \mathrm{~mm}$. Distinct pinching at termination of protoconch, which is knob-like, elongated, and straight. Supra-apical field convex and almost flat from apex to mid-shell length. Subapical field short and concave. Lateral fields almost flat. Apertural outline elliptical in outline. Smooth regular transverse rugae present encircling teleoconch. Partial preservation of pseudomorphic phosphatic coating shows transverse ribs with more relief, closely packed nearer to the aperture (furrows 6-9 $\mu \mathrm{m}$ wide) and more widely spaced toward the apex (furrows 13-23 $\mu \mathrm{m}$ wide) (Fig. 6.14).

\section{Materials.—Approximately 12 steinkerns from HRA 6.}

Remarks.-These specimens are assigned to Stenotheca due to their strong bilateral compression and recurvature (Fig. 6.96.16, 6.19-6.21). Most specimens retain transverse rugae on the exterior of the steinkern teleoconch (Fig. 6.8, 6.9) and, in one specimen, part of the external mold with lirae (Fig. 6.14). These features are present on Stenotheca cf. S. drepanoida from the Parara and Ajax limestones from South Australia (Runnegar in Bengtson et al., 1990, fig. 163B-E). The recurved morphology and bilateral compression are similar to other figured specimens of Stenotheca drepanoida (He and Ting in He et al., 1984) from the Xinji Formation (He et al., 1984, pl. 2, figs. 1-5; Feng et al., 1994, pl. 3, figs. 3, 6) of North China. The morphology of Stenotheca sp. is similar to the apical parts of $S$. drepanoida in having strong bilateral symmetry and recurvature (Gravestock et al., 2001, pl. 43, figs. 1-6) and an egg-shaped protoconch, with a pinch at the transition to the teleoconch (Runnegar in Bengtson et al., 1990, fig. 163G; Gravestock et al., 2001, pl. 43, figs. 8, 9). This feature is not present on all specimens assigned to $S$. drepanoida; specimens from the Mernmerna Formation of
South Australia have a slender, slowly expanding apex without a clear transition to the teleoconch (Topper et al., 2009, fig. 10B-D). Stenotheca transbaikalica Parkhaev, 2004a also has a similar apical part of the shell, with a straightened, more elongate protoconch at an angle to the teleoconch on the subapical field (Parkhaev, 2004a, pl. 2, fig. 3).

Missing from the Shackleton Limestone specimens is information on the aperture. For this reason, Stenotheca sp. has been left in open nomenclature. This may be a taphonomic loss of information potentially due to steinkern-type preservation partially forming molds within quickly dissolving aragonitic shells (i.e., teilsteinkerns). Evidence for this can be seen in the truncation of the rugae at the apertural margin of the specimens (Fig. 6.10, 6.19-6.21) and the relatively small size when compared to specimens from other regions (cf. Parkhaev in Gravestock et al., 2001, p. 183).

\section{Genus Anabarella Vostokova, 1962}

Type species.—Anabarella plana Vostokova 1962 by original designation, Nemakit-Daldynian-Tommotian Stages, Siberia, Russia.

Anabarella cf. A. australis Runnegar in Bengtson et al., 1990 Figure 6.17, 6.18, 6.22

See Supplementary file 1 for taxa assigned to Anabarella australis.

Description.—Strongly bilaterally compressed steinkerns, rapidly expanding and coiled to less than half a whorl. Apex strongly recurved, with subapical field almost circular in profile, subapical margin extended by short parietal train (Fig. 6.17, 6.18). Supra-apical field evenly convex; lateral fields flat. Aperture narrow ellipsis, slightly tapering toward subapical margin. External ornament evident by faint rugae. Extensive polygonal microstructures on younger parts of steinkern but smooth at apex.

Materials.—Three steinkerns from HRSR 66 and HRSK 68.

Remarks.-The specimens are assigned to Anabarella rather than another stenothecid genus due to the greater shell recurvature, subcircular subapical field, and coiling through more than half a whorl (Gubanov and Peel, 2003). In profile, these specimens are most comparable to Anabarella australis, with recurvature and a subapical field similar to A. australis (Runnegar in Bengtson et al., 1990). The polygonal imprints on the surface of the steinkern (Fig. 6.17, 6.18, 6.22) have been observed on the aperture below the apex on some specimens of A. australis (Runnegar in Bengtson et al., 1990, fig. 164N; Parkhaev 2004b, pl. 2, figs. 3, 4), but it lacks the prismatic and fibrous imprints also found on Anabarella plana Vostokova, 1962 (Kouchinsky, 1999). The profile of the specimens from the Shackleton Limestone are most similar to A. australis, but the low number of specimens and polygonal microstructure (typically not present on A. australis) covering the surface of the steinkern prohibit a definitive assignment. 


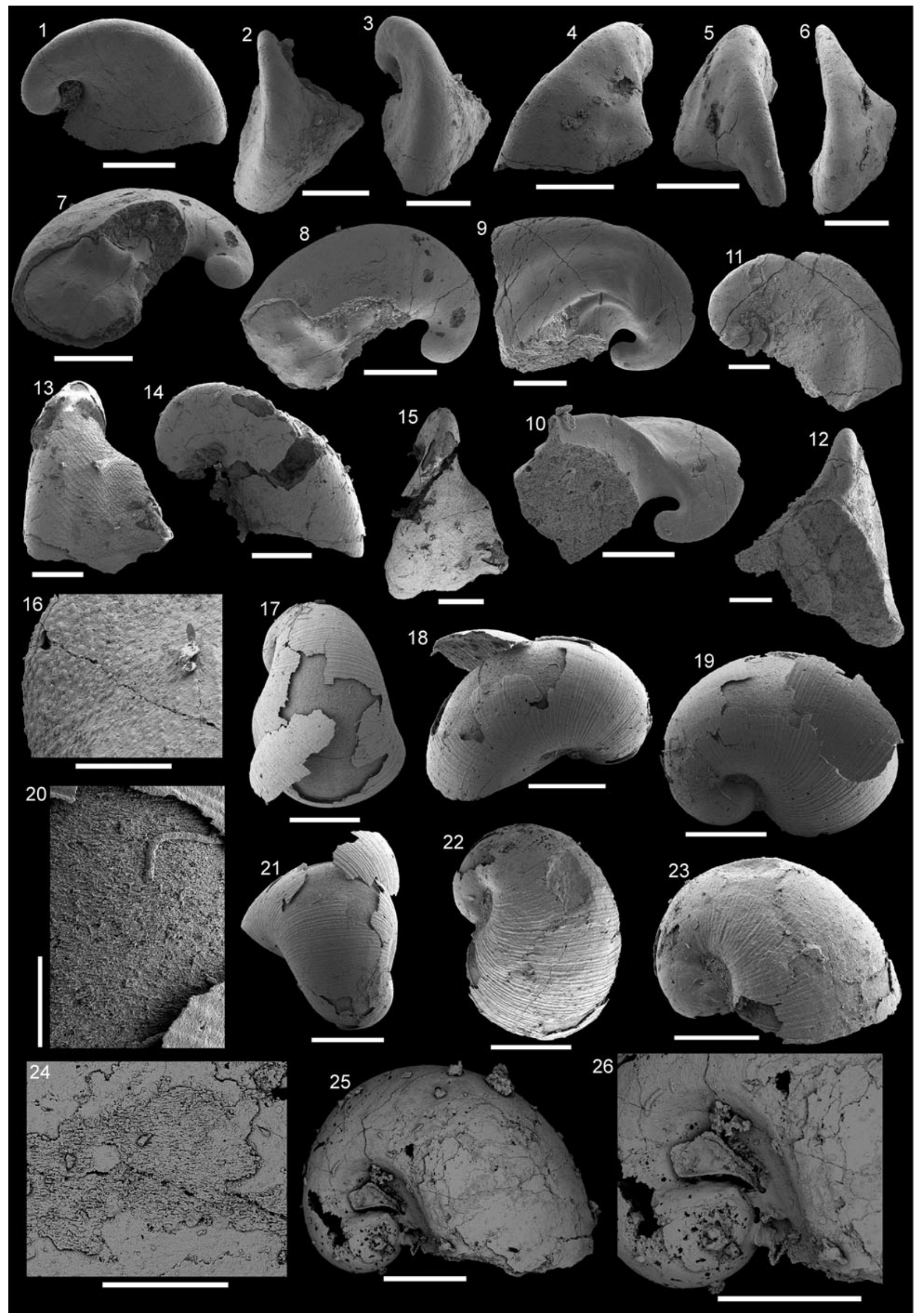




\author{
Total group Gastropoda Cuvier, 1797 \\ Order unknown \\ Family Pelagiellidae Knight, 1956
}

Remarks. - The asymmetrically coiled pelagiellids are one of the better candidates to be considered stem-group gastropods known from the lower Cambrian fossil record. As mentioned previously, authors have indicated an affinity for the gastropods (the Paragastropoda of Lindsey and Kier, 1984 included pelagiellids) or placement within a gastropod order (e.g., 'Archaeogastropoda' Thiele, 1925; see Landing et al., 2002; Parkhaev, 2017a). Their exact placement on the poorly understood stem of the gastropods remains contentious, however, and an ordinal designation to taxa in the gastropod crown-group will not be made here.

\section{Genus Pelagiella Matthew, 1895}

Type species.-Cyrtolites atlantoides Matthew, 1894 by original designation, from the Cambrian Series 2-3 Hanford Brook Formation, St. John Group of New Brunswick, Canada.

\section{Pelagiella cf. P. subangulata (Tate, 1892)}

Figure 5.1-5.16

See Supplementary file 1 for taxa assigned to Pelagiella subangulata.

Lectotype.-SAMP1234a, South Australian Museum, Palaeontological Collections, Adelaide, Australia, designated by Runnegar in Bengston et al. (1990) from the Cambrian Stage 4 Parara Limestone, near Ardrossan, South Australia, Dailyatia odyssei Zone.

Occurrence.-Pelagiella subangulata is known from Cambrian Series 2, Stages 3-4 of South Australia, Laurentia, and South China. Possible specimens known from Cambrian Series 2, Stages 3-4 of East Antarctica, the Great Basins area of the United States, and the middle Cambrian of Germany.

Description.-Anisometrical, dextrally coiled shells with a little over three-quarters of a whorl. Shells rapidly expanding, with slender apex and no clear distinction between teleoconch and protoconch. Total length of steinkerns $0.58 \mathrm{~mm}-0.64 \mathrm{~mm}$, height $0.38 \mathrm{~mm}-0.48 \mathrm{~mm}$. In well-preserved specimens, aperture flares outward from lateral margin of umbilical side, forming subtriangular apertural outline, $0.4 \mathrm{~mm}$ long and $0.2-$ $0.3 \mathrm{~mm}$ wide. Spiral side slightly concave; one specimen preserves distinct narrow ridge ( $70 \mu \mathrm{m}$ high) commencing from near subapical surface and extending to aperture (Fig. 5.9, 5.10). One specimen preserves phosphatic (pseudomorphic) shell material with clear rows of pustulose ornament on the flank of the umbilical side (Fig. 5.13-5.16) converging along shell dorsum. Faint concentric growth lines visible on the concave spiral side of same specimen.

Materials.-Approximately 30 steinkerns, from HRSR 65, 68, HRSK 66, and HRA 2, 4-6, and 42.

Remarks.-Gradational forms between different species of Pelagiella have been identified by numerous authors. Runnegar in Bengtson et al. (1990, p. 253-254) recognized Pelagiella subangulata from South Australia to be variable in size and shape and grade into Pelagiella adunca (He and Pei in He et al., 1984). Parkhaev in Gravestock et al. (2001, p. 194) described a gradation in forms between $P$. subangulata and Pelagiella madianensis (Zhou and Xiao, 1984), but the majority of forms have the general morphologies of one species or the other, and Parkhaev in Gravestock et al., (2001) synonymized $P$. adunca with $P$. subangulata.

Such difficulties in the discrimination of species of Pelagiella have often been overlooked in systematic work. Parkhaev in Gravestock et al. (2001, p. 193) included P. emeishanensis He in Xing et al., 1984 and P. lorenzi Kobayashi, 1939 from 'lower Cambrian' Ludwigsdorf Member, Charlottenhof Formation, Saxony (Elicki 1994, 1996) in P. subangulata without explanation. Wotte and Sundberg (2017) provided an extensive synonymy list with their description of Pelagiella aff. P. subangulata. None of the new synonymies were given with an explanation, and they followed Parkhaev in Gravestock et al. (2001). Many of those included appear to be based on general similarities to $P$. subangulata in overall shape, with no information on microstructure, apertural morphology, or ornamentation. The same broad concept is applied by Wotte and Sundberg (2017) to P. subangulata specimens from the 'lower to middle Cambrian' Campo Pisano Formation, Sardinia (Elicki, 2002; Elicki et al., 2003), the 'middle Cambrian' Láncarna Formation, Spain (Wotte, 2006), and the Marianian (Cambrian ?Stages 3-4) Upper Ludwigsdorf Member, Charlottenshof Formation, Saxony (Elicki, 2003). These should be only tentatively assigned to $P$. subangulata (Supplementary file 1), as the specimens are unornamented steinkerns, lacking microstructural details and often poorly preserved (Elicki, 2002, pl. 1; Elicki, 2003, pl. 2, fig. 1; Elicki et al., 2003, pl. 5, figs. 3-5; Wotte, 2006, fig. 5n-p).

Specimens from the Shackleton Limestone are tentatively assigned to Pelagiella cf. P. subangulata based only on general morphological features. These include rapidly expanding whorls (Fig. 5.1, 5.9, 5.14), an initially concave then convex apical side

Figure 6. Pelagiellids from the Shackleton Limestone. (1-16) Pelagiella cf. P. subangulata Tate, 1892, (1-3) specimen SMNH Mo185054, (1) view of spiral side, (2) dorsal view, (3) dorsal view of supra-apical field; (4-6) specimen SMNH Mo185055, (4) apical view, (5) apical view, (6) dorsal view; (7, 8) specimen SMNH Mo185056, with possible hyolith operculum embedded in aperture, (7) oblique apertural view, (8) umbilical side; (9, 10) specimen SMNH Mo185057, (9) lateral view of abapical side, (10) oblique apertural view, showing curved groove passing through the umbilicus; (11, 12) specimen SMNH Mo185058, (11) apical view, (12) apertural view; (13-16) specimen SMNH Mo185059, (13) view of supra-apical field, (14) apical view, (15) dorsal view, (16); magnified dorsal view of part of the abapical side on the projecting wing, showing pustulose ornamentation. (17-26) Xinjispira simplex Zhou and Xiao, 1984, (17-21) specimen SMNH Mo185060, (17) oblique dorsal view of supra-apical field, (18) lateral view of abapical side, (19) lateral view of apical side, (20) magnification of internal mold with transverse fibrillar crystalline imprints, (21) view of supra-apical field; (22, 23), specimen SMNH Mo185061, (22) dorsal view, (23) lateral view of apical side; (24-26) specimen SMNH Mo185062, (24) apical view, (25) maginification of circumbilical channel on apical side, (26) magnification of transverse fibers on supra-apical surface of the steinkern. $(\mathbf{1 6 , 2 0 , 2 4})$ Scale bars $=100 \mu \mathrm{m}$; all others, scale bars $=200 \mu \mathrm{m}$. All images taken using secondary electrons except (24-26) taken using backscattered electrons. 
(Fig. 5.2, 5.6), and a projecting wing on the abapical side (Fig. 5.2, 5.12, 5.15; see also Runnegar in Bengtson et al., 1990 , p. 254). The variation displayed in specimens from the Shackleton Limestone are both morphological and taphonomic. Specimens range from having a broader aperture (Fig. 5.2, 5.7, 5.12) to a narrower aperture (Fig. 5.5, 5.6). The low number of $P$. cf. $P$. subangulata steinkerns from the Shackleton Limestone (27 steinkerns), with only one similar to the $P$. madianensis morphology, does not allow a detailed comparison of aperture size and shape and degree of coiling. Two figured specimens (Fig. 5.7-5.10) show clear taphonomic artifacts common to steinkern-type preservation. One specimen preserves a possible hyolith operculum in its aperture (Fig. 5.7, 5.8) and one material introduced then lost during formation, represented by a groove across the umbilicus of the steinkern in Figure 5.9-5.10.

A detailed study of Pelagiella madianensis from the Xinji Formation (Cambrian Series 2), North China, has recently shown the shell microstructure to be a complex of four hierarchical types, signifying complex and differentiated controls on biomineralization in early mollusks (Li et al., 2017). Unfortunately, steinkerns from the Shackleton Limestone have smooth surfaces lacking any remnant microstructure. One specimen has a pustulose ornamentation, running obliquely toward the aperture (Fig. 5.13, 5.15). This is similar to the ornament figured by Runnegar in Bengtson et al. (1990, fig. 167A-E) but lacks the clear chevron pattern of their specimen.

Family Pelagiellidae? Knight, 1956

Genus Xinjispira Yu and Rong, 1991

Type species.-Xinjispira simplex Zhou and Xiao, 1984 from the lower Cambrian Xinji Formation (=Yutaishan Formation), Anhui Province, China.

Xinjispira simplex Zhou and Xiao, 1984

Figure 5.17-5.26

1984 Barskovia simplex Zhou and Xiao, p. 135, pl. 4, figs. 6-12. 1987a Xinjispira simplex; Yu, p. 54, pl. 4, figs. 14-16.

1987b Xinjispira simplex; Yu, p. 210, pl. 68, figs. 1-6.

1990 Xinjispira simplex; Yu, p. 146, fig. 4.

1991 Xinjispira simplex; Yu and Rong, p. 341, pl. 1, figs. 10-13.

1994 Xinjispira simplex; Feng et al., p. 13, pl. 1, figs. 14-18. 2016 Xinjispira simplex; Yun et al., p. 59, fig. 5L.

Holotype.-No. 800096, Geological Institute, Anhui Province, People's Republic of China. Internal mold from the Xinji Formation (=Yutaishan Formation) of the lower Cambrian (Series 2) of the North China Platform of Anhui Province, China.

Occurrence.-Xinjispira simplex is known from the Cambrian Series 2, Stages 3-4, of the southern margin of the North China Platform and from the Cambrian Series 2, Stages 3-4, of East Antarctica.

Description.-Turbospiral, globose, coiled through almost one whorl. Slight projection of apex on apical side, but no spire present. Aperture rounded, with small projecting wing on abapical side of the shell. Aperture approximately $0.3 \mathrm{~mm}$ long and $0.4 \mathrm{~mm}$ wide. Total length $0.5-0.6 \mathrm{~mm}$ and height $0.4 \mathrm{~mm}$. No clear distinction between protoconch and teleoconch, but may be marked by beginning of lirae. Pseudomorphic phosphatic shell coating with regular transverse lirae, $10 \mu \mathrm{m}$ in width. Internal mold preserved imprints of comarginal fibrous bundles parallel to the ribs; some evidence of endolithic bacteria in form of phosphatized strands (Fig. 5.20). Umbilicus present on one specimen, with circumbilical channel (Fig. 5.25, 5.26).

Materials.-Approximately 10 steinkerns from HRSK 66, HRA 4, 5; with two steinkerns from HRSK 66 with external ornament preserved.

Remarks. - Xinjispira was assigned to the pelagiellids by Zhou and Xiao (1984), but later authors assigned them to the macluritids (Yu and Rong, 1991; Feng et al., 1994), in both cases considered gastropods. Yu and Rong (1991, p. 344) go so far as to say their specimens are missing their operculae. Parkhaev in Gravestock et al. (2001) and Parkhaev (2002, 2007a) placed Xinjispira with the family Khairkhaniidae Missarzhevsky, 1989. The use of the family Khairkaniidae as defined in Parkhaev in Gravestock et al. (2001) and Parkhaev (2002) is not used here due to issues regarding the inclusion of symmetric (Protowenella) and asymmetric (e.g., Xinjispira, Barskovia Golubev, 1976) forms, under the assumption that they form a phylogenetic series. As no formal phylogenetic analysis has been performed to support this hypothesis, Xinjispira is tentatively included here with the pelagiellids. The inclusion in the pelagiellids is supported by their lack of spire on the concave apical side (Fig. 5.19, 5.23, 5.25), small projecting wing on the abapical side of the shell (Fig. 5.17, 5.21), and transverse fibrous microstructure preserved on the steinkern (Fig. 5.20, 5.24; cf. Li et al., 2017, fig. 3), which indicate an affinity with this family. Although microstructural imprints do not always preserve and similar patterns can appear in different lineages of early shelled molluscs, this microstructure, lack of spire, and noncircular aperture lead to a stronger argument for their inclusion in the pelagiellids.

Specimens figured by Zhou and Xiao (1984), Feng et al. (1994), Yu (1990), Yu and Rong (1991), and Yun et al. (2016) from the Xinji Formation are all 'sinistrally' coiled (when viewed from the apical, older end of the shell), whereas under the same scheme, Xinjispira simplex specimens from the Shackleton Limestone would be considered 'dextrally' coiled. In a review of shell chirality in the Cambrian asymmetrically coiled univalved mollusk Aldanella Vostokova 1962, Parkhaev (2007b) agreed with earlier conclusions of Landing (1988) and Landing et al. (1989) that chiral members of the same species are 'aberrations' or exceptions, that is, those that coil in the opposite direction to most members of a species. From the Tommotian Stage of Siberia, sinistral forms of Aldanella from a single stratigraphic horizon were reported and speculated to be members of a new species, rather than aberrations (Parkhaev, 2007b; but see Jacquet et al., 2017 for comments on Australian sinistral Aldanella). In their diagnosis of Pelagiellidae, Lindsey and Kier (1984, p. 250) included only 

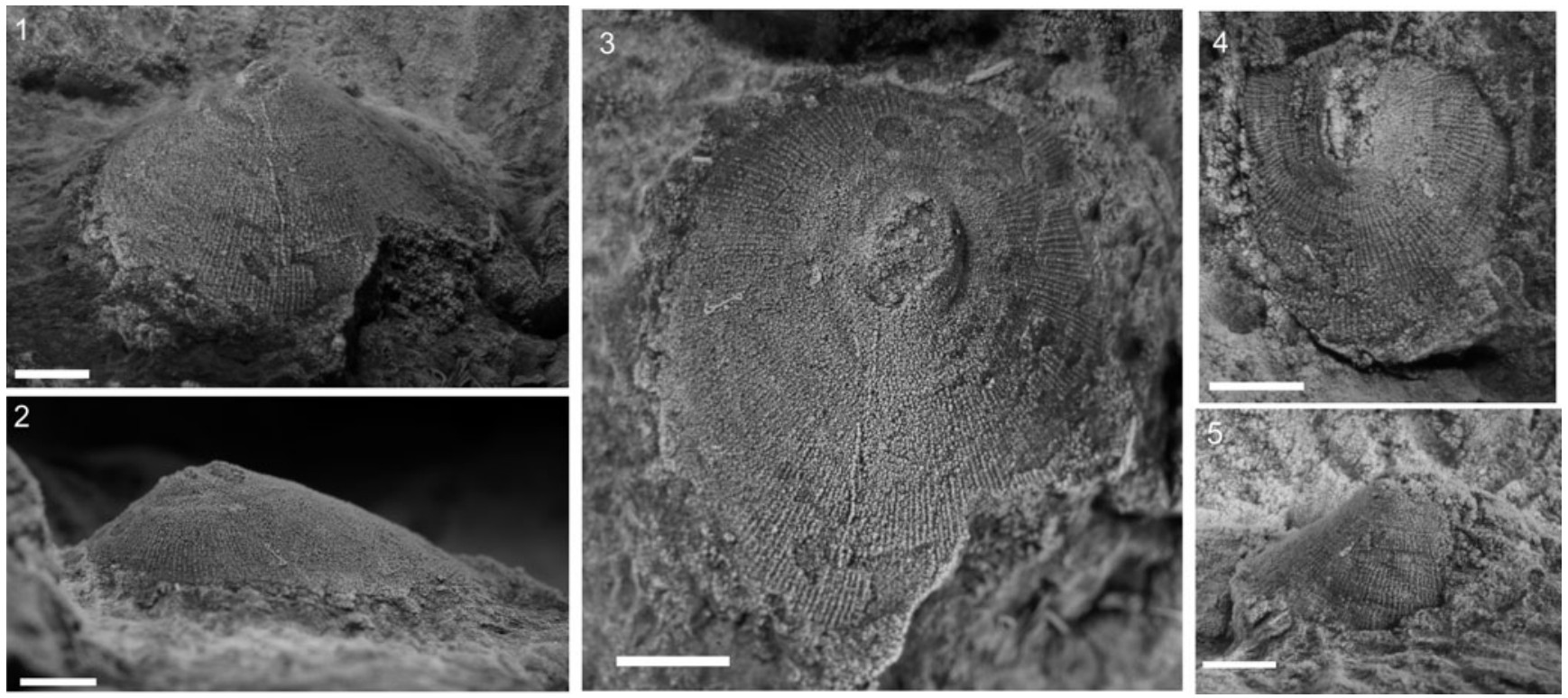

Figure 7. Scenella? sp. from the Shackleton Limestone. (1-3) Specimen SMNH Mo185075, (1) oblique view along supra-apical field, (2) lateral view, (3) apical view. $(\mathbf{4}, \mathbf{5})$ Specimen SMNH Mo185076, (4) apical view, (5) lateral view, angled obliquely toward subapical field. Scale bars $=2 \mathrm{~mm}$.

dextral forms, indicating the sinistral forms of Xinjispira simplex could not be included in the family. Whether X. simplex from the Shackleton Limestone can be considered 'aberrant' or of a new species is uncertain due to their low abundance. A comprehensive review of sinistrally coiled forms of Cambrian helcionelloids is probably necessary to resolve the paleobiological relevance of chirality and resolve taxonomic questions.

Only Yu and Rong (1991, p. 344) report 'growth lines' ornamenting the surface, but this is not defined, or clear in their figures, whereas Antarctic specimens retain both transverse fibrous microstructure (Fig. 5.20, 5.24) on the steinkern and transverse costae (Fig. 5.17-5.19, 5.21-5.23) on phosphatized exteriors. Of the two Shackleton Limestone specimens, one has a well-developed but small projecting wing (Fig. 5.17, 5.21) similar to that figured in Zhou and Xiao (1984, pl. 4, fig. 7c) and Feng et al. (1994, pl. 2, fig. 18), which is apparently not always well preserved or developed. Yu (1987b, p. 210) described two umbilical channels on the apical and abapical sides of Xinjispira, similar to those preserved on steinkerns of Protowenella. Circumbilical channels are exposed on a specimen of $X$. simplex from the Shackleton Limestone that is lacking an external phosphatic coating (Fig. 5.25, 5.26).

Class, Order, and Family unknown

Remarks.-The placement of Scenella in the chondrophorine (or porpitid) hydrozoans has been reviewed in detail by Landing et al. (2018, p. 113-114), who concluded Scenella is a mollusk and the "chondrophorine paradigm" of incorrectly identified Cambrian macromollusks is unwarranted. This better resolved placement in the mollusks is unlikely to resolve its taxonomic position. The genus has, for example, been considered a member of the helcionellaceans, within the monoplacophora (Runnegar and Jell, 1976) and as a helcionelloid (Peel, 1991a; see Isakar and Peel, 2007, p. 255-256 for a review of the taxonomic history of Scenella as a mollusk). Due to the low number of specimens described here and the uncertainty surrounding the taxonomy of Scenella, an attempt to rectify its higher taxonomic relationships shall not be made.

\section{Genus Scenella Billings, 1872}

Type species. - Scenella reticulata Billings, 1872 by original designation, from the Branchian Stage (Series 2) Brigus Formation of Newfoundland, Canada.

\section{Scenella? sp.}

Figure 7

Description.-Patelliform, univalved, low, blunt shells and very rapidly expanding. Single unbroken specimen has apetural length $9.8 \mathrm{~mm}$ and width $8.5 \mathrm{~mm}$; elliptical in outline. Height $3.1 \mathrm{~mm}$; specimen three times as long as it is high. Apex offset from center; subapical field less than half the length of the supra-apical field, creating an angle of ca. $110^{\circ}$. Both fields gently convex; supra-apical field concave nearer to apex. Protoconch poorly preserved; apical parts of both specimens damaged. External ornamentation consists of fine radial ribs. No concentric growth lines or ribs present. No muscle scars visible.

Materials.-Two silicified shells from HRA 14 and HRSG 59.

Remarks.-Placement of the specimens of Scenella? sp. from the Shackleton Limestone in a group of similar, simple, patelliform mollusks is problematic. As noted in Jacquet and Brock (2016), Scenella is a wastebasket taxon of dubious taxonomic validity. Its problematic history once led to its inclusion in the derived group of chondrophorine hydrozoans (e.g., Yochelson and Gil Cid, 1984; Babcock and Robison, 1988; Narbonne et al., 1991). It is herein considered a mollusk, following its reidentification by a number of authors (e.g., Conway Morris and Peel, 2013; Peel, 1991b, 2003; 
Landing and Narbonne, 1992; Geyer, 1994; Landing et al., 2018). In lieu of a much-needed systematic revision of the genus, the specimens from the Shackleton Limestone are referred to Scenella? sp. due to the broadly encompassing description of the genus as having a low patelliform profile (Fig. 7.2, 7.5), subcentral apex, elliptical outline (Fig. 7.3), and subdued concentric rugae and lirae (Billings, 1872, p. 479; Knight, 1941 , p. 309-310, pl. 2, fig. 5a-e). The specimens from the Shackleton Limestone fit all criteria except the presence of either concentric comarginal rugae or growth lines, only bearing fine radial ribs (Fig. 7). Scenella? sp. from the Shackleton Limestone shares this lack of concentric features with Scenella amii (Matthew, 1902) from the middle Cambrian Stephen Formation of British Colombia, Canada, and Scenella radians Babcock and Robison, 1988 from the Drumian (Series 3) Spence Shale and Chisholm Formation of Utah, USA, but compares more closely to the latter. Figured specimens of $S$. radians also share the offset apex and concave part of the supra-apical field just below the apex (Babcock and Robison, 1988, fig. 4.1-4.5). The lack of concentric features prevents a more certain inclusion of the Shackleton Limestone specimens in the genus Scenella and indicates that species such as $S$. amii and $S$. radians may also be incorrectly placed in this genus. The diagnosis for $S$. radians is also written under the assumption it is a chondrophonrine hydrozoan, hindering a better comparison to other Cambrian univalved mollusks (Babcock and Robison, 1988, p. 10). Scenella? sp. differs from the similarly ornamented and shaped Scenella barrandei (Linnarsson, 1879) in having an elliptical, rather than subrectangular, apertural outline (Berg-Madsen and Peel, 1986, fig. 2d) and lack of comarginal rugae (Berg-Madsen and Peel, 1986, figs. 2c, 3e). The type species, $S$. reticulata, has a distinct reticulate ornamentation formed by radial and concentric ribs. Figures in Knight (1941, pl. 2, fig. 5a-e) and Landing (1988, fig. 12.1, 12.2) show $S$. reticulata has a higher shell and apex offset further over the subapical field, giving the subapical field an almost vertical profile.

Scenella? sp. from the Shackleton Limestone can be excluded from the similar monospecific genus Estoniadiscus Peel 2003 from the lower Cambrian Tiskre Formation of Estonia, as Estoniadiscus has 'wrinkled' periodic ribs and a more circular, less elliptical outline. The apex is also offset toward the supra-apical field. These features are figured by Peel (2003) for the species Estoniadiscus discinoides (Schmidt, 1888). From the monospecific Galeaclavus Jacquet and Brock, 2016 from the Third Plains Creek Member of the Mernmerna Formation (Cambrian Series 2, Stage 3) of South Australia, Scenella? sp. can be excluded due to a lack of faint comarginal growth lines present on Galeaclavus coronarius (Jacquet and Brock, 2016, fig. 12 A, D) and G. coronarius having a more inclined apex. Scenella? sp. also has a much lower profile, with height-to-length ratio of 0.31 , just below the lowest measured height-to-length ratio of 0.33 for $G$. coronarius.

\section{Acknowledgments}

The work by LEH was supported by grants from the Swedish Research Council (VR 2009-4395, 2012-1658). The field work in Antarctica was supported by operational support for polar research (RFI Polar VR 2010-6176) and the Swedish Polar Secretariat in collaboration with the United States Antarctic Program and U.S. National Science Foundation (NSF). GAB was supported in Antarctica by a Trans-Antarctic Association Grant. D. Taylor, P. Myrow, and L. Stemmerik were integral parts of the fieldwork team in Antarctica. Processing of rock samples was performed by D. Mathieson (Macquarie University) and T. Hultgren (Uppsala University). TMC would like to thank B. Pan, L. Li, and H. Yun for discussions on North Chinese specimens and stratigraphy. We also thank A.P. Gubanov and E. Landing for their constructive reviews.

\section{Accessibility of supplemental data}

Data available from the Dryad Digital Repository: https://doi. org/10.5061/dryad.3bb462v.

\section{References}

Atkins, C.J., and Peel, J.S., 2004, New species of Yochelcionella (Mollusca; Helcionelloida) from the lower Cambrian of North Greenland: Bulletin of the Geological Society of Denmark, v. 1020, p. 1-9.

Atkins, C.J., and Peel, J.S., 2008, Yochelcionella (Mollusca, Helcionelloida) from the lower Cambrain of North America: Bulletin of Geosciences, v. 83 , p. $23-38$.

Babcock, L.E., and Robison, R.A., 1988, Taxonomy and paleobiology of some middle Cambrian Scenella (Cnidaria) and Hyolithids (Mollusca) from Western North America: The University of Kansas Paleontological Contributions, Paper 121, $22 \mathrm{p}$.

Babcock, L.E., Peng, A., and Ahlberg, P., 2017, Cambrian trilobite biostratigraphy and its role in developing an integrated history of the Earth system: Lethaia, v. 50, p. 381-399.

Bengtson, S., 2004, Early skeletal fossils: Paleontological Society Papers, v. 10, p. $67-77$.

Bengtson, S., Conway Morris, S., Cooper, B.J., Jell, P.A., and Runnegar, B.N., 1990, Early Cambrian fossils from South Australia: Association of Australasian Palaeontologists Memoirs, v. 9, 364 p.

Berg-Madsen, V., and Peel, J.S., 1978, Middle Cambrian monplacophorans from Bornholm and Australia, and the systematic position of the bellerophontiform molluscs: Lethaia, v. 11, p. 113-125.

Berg-Madsen, V., and Peel, J.S., 1986, Scenella barrandei (Mollusca) from the middle Cambrian of Baltoscandia: Norsk Geologisk Tidsskrift, v. 66, p. 81-86.

Betts, M.J., Paterson, J.R., Jago, J.B., Jacquet, S.M., Skovsted, C.B. Topper, T.P., and Brock, G.A., 2016a, A new lower Cambrian shelly fossil biostratigraphy for South Australia: Gondwana Research, v. 36, p. 176-208.

Betts, M.J., Paterson, J.R., Jago, J.B., Jacquet, S.M., Skovsted, C.B., Topper, T.P., and Brock, G.A., 2016b, A new lower Cambrian shelly fossil biostratigraphy for South Australia: Reply: Gondwana Research, v. 44, p. 262-264.

Betts, M.J., Paterson, J.R., Jago, J.B., Jacquet, S.M., Skovsted, C.B., Topper, T.P., and Brock, G.A., 2017, Global correlation of the early Cambrian of South Australia: Shelly fauna of the Dailyatia odyssei Zone: Gondwana Research, v. 46, p. 240-179.

Billings, E., 1872, On some fossils from the primordial rocks of Newfoundland Canadian Naturalist and Geologist, v. 6, p. 465-479.

Boger, S.D., and Miller, J.McL., 2004, Terminal suturing of Gondwana and the onset of the Ross-Delmarian Orogeny: The cause and effect of an early Cambrian reconfiguration of plate motions: Earth and Planetary Science Letters, v. 219, p. 35-48.

Brock, G.A., 1998, Middle Cambrian molluscs from the southern New England fold belt, New South Wales, Australia: Geobios, v. 31, p. 571-586.

Brock, G.A., Engelbrechtsen, M.J., Jago, J.B., Kruse, P.D., Laurie, J.R., Shergold, J.H., Shi, G.R., and Sorauf, J.E., 2000, Palaeobiogeographic affinities of Australian Cambrian faunas: Memoir of the Association of Australasian Palaeontologists, v. 12, p. 1-61

Burgess, C.J., and Lammerink, W., 1979, Geology of the Shackleton Limestone (Cambrian) in the Byrd Glacier area: New Zealand Antarctic Record, v. 2, p. $12-16$.

Conway Morris, S., and Peel, J.S., 2013, A new helcionelloid mollusk from the middle Cambrian Burgess Shale, Canada: Journal of Paleontology, v. 87, p. $1067-1070$.

Creveling, J.R., Knoll, A.H., and Johnston, D.T., 2014, Taphonomy of Cambrian Phosphatic Small Shelly Fossils: Palaios, v. 29, p. 295-308. 
Cuvier, G., 1797, Tableau élémentaire de l'histoire naturelle des animaux: Paris, Baudouin.

Dattilo, B.F., Freeman, R.L., Peters, W.S., Heimbrock, W.P., Deline, B., Martin, J., Kallmeyer, J.W., Reeder, J., and Argast, A., 2016, Giants among micromorphs: Were Cincinnatian (Ordovician, Katian) small shelly phosphatic faunas dwarfed: Palaios, v. 31, p. 55-70.

Debrenne, F., and Kruse, P.D., 1986, Shackleton Limestone archaeocyaths: Alcheringa: An Australasian Journal of Palaeontology, v. 10, p. 235-278.

Debrenne, F., and Kruse, P.D., 1989, Cambrian Antarctic archaeocyaths, in Crame, J.A., ed., Origins and Evolution of Antarctic Biota: Geological Society Special Publication 47, p. 15-28.

Elicki, O., 1994, Lower Cambrian carbonates from eastern Germany: Paleontology, stratigraphy and palaeogeography: Neues Jahrbuch für Geologie und Paläontologie-Abhandlungen, v. 191, p. 69-93.

Elicki, O., 1996, Die Gastropoden und Monoplacophoran der unterkambrischen Görlitz-Fauna: Feriberger Forschungshefte, C 464, Paläontologie, Stratigraphie, Fazies, v. 3, p. 145-173 [in German with English abstract].

Elicki, O., 2002, First record of Cambrian pelagiellids from Sardinia: Freiberger Forschungshefte, C 464, Paläontologie, Stratigraphie, Fazies, v.10, p. 19-27.

Elicki, O., 2003, Das Kambrium Saschens: Veröffentlichungen des Museumsfür Naturkunde Chemnitz, v. 26, p. 41-62 [in German with English abstract].

Elicki, O., and Gürsu, S., 2009, First record of Pojetaia runnegari Jell, 1980 and Fordilla Barrande, 1881 from the Middle East (Taurus Mountains, Turkey) and critical review of Cambrian bivalves: Palaontologische Zeitschrift, v. 83 , p. $267-291$.

Elicki, O., Hamman, Y., and Münzberger, P., 2003, Biofazies, Paläoökologie und Ablagerungsmodell des Finalstadiums einer kambrischen Karbonatplattform- Entwicklung: die Fauna der Campo Pisano Formation SW-Sardiniens: Freiberger Forschungshefte, C 499 Paläontologie, Stratigraphie, Fazies, v. 11, p. 1-33 [in German with English abstract]

Esakova, N.V., and Zhegallo, E.A., 1996, Fauna and Biostratigraphy of the Lower Cambrian of Mongolia: Moscow, Nauka, 219 p. [in Russian].

Evans, K.R., 1992, Marocella: Antarctic specimens of an enigmatic Cambrian animal: Journal of Paleontology, v. 66, p. 558-562.

Evans, K.R., and Rowell, A.J., 1990, Small shelly fossils from Antarctica: An early Cambrian faunal connection with Australia: Journal of Paleontology, v. 64, p. $692-700$.

Feng, W., Qian, Y., and Rong, Z-q., 1994, Study of Monoplacophora and Gastropoda from the Lower Cambrian Xinji Formation in Ye Xian, Henan: Acta Micropalaeontologica Sinica, v. 11, p. 1-19 [in Chinese with English summary].

Gaździcki, A., and Wrona, R., 1986, Polski badania paleontologiczne w Antarktyce zachodneij: Przegląd Geologiczny, v. 34, p. 609-616 [in Polish with English summary].

Geyer, G., 1994, Middle Cambrian molluscs from Idaho and early conchiferan evolution: New York State Museum Bulletin, v. 481, p. 69-86.

Geyer, G., and Shergold, J., 2000, The quest for internationally recognized divisions of Cambrian time: Episodes, v. 23, p. 188-195.

Golikov, A.N., and Starobogatov, Y.I., 1975, Systematics of prosobranch gastropods: Malacologia, v. 15, p. 185-232.

Golubev, S.N., 1976, Ontogenetic changes and evolutionary trends in early Cambrian spiral gastropods of the superfamily Pelagiellacea: Paleontological Journal, v. 10, p. 143-149.

Goodge, J.W., Walker, N.W., and Hansen, V.L., 1993, NeoproterozoicCambrian basement-involved orogenesis within the Antarctic margin of Gondwana: Geology, v. 21, p. 37-40.

Goodge, J.W., Myrow, P., Philips, D., Fanning, C.M., and Williams, I.S., 2004, Siliciclastic record of rapid denudation in response to convergent-margin orogenesis, Ross Orogen, Antarctica: Special Paper of the Geological Society of America, v. 378, p.105-126.

Gravestock, D.I., et al., 2001, The Cambrian biostratigraphy of the Stansbury Basin, South Australia: Transactions of the Palaeontological Institute, v. 282,345 p.

Gubanov, A.P., and Peel, J.S., 2000, Cambrian monoplacophoran molluscs (Class Helcionelloida): American Malacological Bulletin, v. 14, p. 139-145.

Gubanov, A.P., and Peel, J.S., 2001, Latest helcionelloid molluscs from the Lower Ordovician of Kazakhstan: Palaeontology, v. 44, p. 681-694.

Gubanov, A.P., and Peel, J.S., 2003, The early Cambrian Helcionelloid mollusc Anabarella Vostokova: Palaeontology, v. 46, p. 1073-1087.

Gubanov, A.P., Kouchinsky, A.V., Peel, J.S., Bengtson, S., 2004, Middle Cambrian molluscs of 'Australian' aspect from northern Siberia: Alcheringa, v. 28 , p. $1-20$

Guo, J., Li, Y., and Li, G., 2014, Small shelly fossils from the early Cambrian Yanjiahe Formation, Yichang, Hubei, China: Gondwana Research, v. 25, 999-1007.

He, T., and Pei, F., 1985, The discovery of bivalves from the lower Cambrian Zinji Formation in Fangcheng County, Henan Province: Journal of Chengdu College of Geology, p. 151-159 [in Chinese with English summary]
He, T., and Yang, X., 1982, Lower Cambrian Meishucun Stage of the Western Yangtze Stratigraphic region and its small shelly fossils: Bulletin of the Chengdu Institute of Geology and Mineral Resources, Chinese Academy of Geological Sciences, v. 3, p. 69-95 [in Chinese].

He, T., Pei, F., and Fu, G., 1984, Some small shelly fossils from the lower Cambrian Xinji Formation in Fangcheng County, Henan Province: Acta Palaeontologica Sinica, v. 23, p. 350-357 [in Chinese with English summary].

Heuse, T., Blumenstengel, H., Elicki, O., Geyer, G., Hansch, W., Maletz, J., Sarmiento, G.N., and Weyer, D., 2010, Biostratigraphy-The faunal province of the southern margin of the Rheic Ocean, in Linnemann, U., and Romer, R.L., eds., Pre-Mesozoic Geology of Saxo-Thuringia-From the Cadomian Active Margin to the Variscan Orogen: Stuttgart, Schweizerbart, p. $99-170$.

Hicks, H., 1872, On some undescribed fossils from the Menevian Group of Wales: Quarterly Journal of the Geological Society of London, v. 28, p. $173-185$.

Holmer, L.E., Popov, L.E., and Wrona, R., 1996, Early Cambrian lingulate brachiopods from glacial erratics of King George Island (South Shetland Islands), Antarctica: Palaeontologica Polonica, v. 55, p. 37-50.

Høyberget, M., Ebbestad, J.O.R., Funke, B., and Nakrem, H.A., 2015, The shell fauna and biostratigraphy of the lower Cambrian (provisional series 2, stage 4) Evjevik Member, Ringstrand Formation in the Mjøsa area, Norway: Norwegian Journal of Geology, v. 95, p. 23-56.

Isakar, M., and Peel, J.S., 2007, Lower Cambrian helcionelloid molluses from Estonia: GFF, v. 129, p. 255-262

Jackson, I.S.C., and Claybourn, T.M., 2018, Morphometric analysis of interand intraspecific variation in the Cambrian helcionelloid mollusc Mackinnonia: Palaeontology, v. 61, p. 761-773.

Jacquet, S.M., and Brock, G.A., 2016, Lower Cambrian helcionelloid macromolluscs from South Australia: Gondwana Research, v. 36, p. 333-358.

Jacquet, S.M., Betts, M.J. and Brock, G.A., 2016a, Phosphate, facies and fossilisation of Cambrian molluscs: Palaeo Down Under 2, Adelaide, Abstracts with Programme, p. 36.

Jacquet, S.M., Jago, J.B., and Brock, G.A., 2016b, An enigmatic univalve macromollusc from the lower Cambrian (Series 2, Stage 3) Heatherdale Shale, South Australia: Australian Palaeontological Memoirs, v. 49, p. 21-30.

Jacquet, S.M., Brougham, T., Skovsted, C.B., Jago, J.B., Laurie, J.R. Betts, M.J., Topper, T.P., and Brock, G.A., 2017, Watsonella crosbyi from the lower Cambrian (Terreneuvian, Stage 2) Normanville Group in South Australia: Geological Magazine, v. 154, p. 1088-1104

Jago, J.B., Gehling, J.G., Paterson, J.R., Brock, G.A., and Zang, W., 2012, Cambrian stratigraphy and biostratigraphy of the Flinders Ranges and the north coast of Kangaroo Island, South Australia: Episodes, v. 35, p. 247-255.

Jell, P.A., 1980, Earliest known pelecypod on Earth-A new early Cambrian genus from South Australia: Alcheringa: An Australasian Journal of Palaeontology, v. 4, p. 233-239.

Jeppsson, L., Anehus, R., and Fredholm, D., 1999, The optimal acetate buffered acetic acid technique for extracting phosphatic fossils: Journal of Paleontology, v. 73, p. 964-972.

Khomentovsky, V.V., Val'kov, A.K., and Karlove, G.A., 1990, [New data of the biostratigraphy of transitional Vendian-Cambrian strata in the middle reaches of the River Aldan], in Khomentovsky, V.V., Yakshin, M.S., and Karlove, G.A., eds., [Late Precambrian and Early Palaeozoic of Siberia. Vendian deposits]: Novosibirsk, Institut geologii i geofiziki SO AN SSSR, p. 29-44 [in Russian].

Knight, J.B., 1941, Paleozoic gastropod genotypes: Geological Society of America, Special Paper 32, 503 p.

Knight, J.B., 1952, Primitive gastropods and their bearing on gastropod evolution: Smithsonian Miscellaneous Collections, v. 117, 56 p.

Knight, J.B., 1956, New families of Gastropoda: Journal of the Washington Academy of Sciences, v. 46, p. 41-42.

Knight, I., Boyce, W.D., Skovsted, C.B., and Balthasar, U., 2017, The lower Cambrian Forteau Formation, southern Labrador and Great Northern Peninsula, western Newfoundland: Lithostratigraphy, trilobites, and depositional setting: Government of Newfoundland and Labrador, Department of Natural Resources, Geological Survey, St. John's, Occasional Paper 2017-01, 72 p.

Kobayashi, T., 1939, Restudy on Lorentz's Raphistoma broeggeri from Shantung with a note on Pelagiella: Jubilee Publication in Commemoration of Prof. H. Yabe's 60th birthday, p. 283-288.

Kouchinsky, A., 1999, Shell microstructures of the early Cambrian Anabarella and Watsonella as new evidence on the origin of the Rostroconchia: Lethaia, v. 32, p.173-180.

Kouchinsky, A., 2000, Shell microstructure in early Cambrian molluscs: Acta Palaeontologica Polonica, v. 45, p. 119-150.

Kouchinsky, A., Bengtson, S., Runnegar, B.N., Skovsted, C.B., Steiner, M., and Vendrasco, M.J., 2012, Chronology of early Cambrian biomineralization: Geological Magazine, v. 149, p. 221-251. 
Kouchinsky, A., Bengtson, S., Clausen, S., and Vendrasco, M.J., 2015, An early Cambrian fauna of skeletal fossils from the Emyaksin Formation, northern Siberia: Acta Palaeontologica Polonica, v. 60, p. 421-512.

Laird, M.G., Mansergh, G.D., and Chappell, J.M.A., 1971, Geology of the Nimrod Glacier area, Antarctica: New Zealand Journal of Geology and Geophysics, v. 14, p. 427-468.

Landing, E., 1988, Lower Cambrian stratigraphy of Eastern Massachusetts: Stratigraphy and small shelly fossils: Journal of Paleontology, v. 62, p. 661-695.

Landing, E., 1992, Lower Cambrian of southeastern Newfoundland: Epeirogeny and Lazarus faunas, lithofacies-biofacies linkages, and the myth of a global chronostratigraphy, in Lipps, J.H., and Signor, P.W. eds., Origins and Early Evolution of the Metazoa: New York, Plenum Press, p. 283-309.

Landing, E., and Bartowski, K.E., 1996, Oldest shelly fossils from the Taconic Allochthon and late early Cambrian sea-levels in eastern Laurentia: Journal of Paleontology, v. 70, p. 741-761.

Landing, E., and Narbonne, G.M., 1992, Scenella and "a chondrophorine (medusoid hydrozoan) from the basal Cambrian (Placentian) of Newfoundland": Journal of Paleontology, v. 66, p. 338.

Landing, E., Myrow, P., Benus, A.P., and Narbonne, G.M., 1989, The Placentian Series: Appearance of the oldest skeletonized faunas in southeastern Newfoundland: Journal of Paleontology, v. 63, p. 739-769.

Landing, E., Geyer, G., and Bartowski, K. E., 2002, Latest early Cambrian small shelly fossils, trilobites and Hatch Hill dysaerobic interval on the Québec continental slope: Journal of Paleontology, v. 76, p. 287-305.

Landing, E.D., Geyer, G., Brasier, M.D., and Bowring, S.A., 2013, Cambrian evolutionary radiation: Context, correlation, and chronostratigraphy-Overcoming deficiencies of the first appearance datum (FAD) concept: EarthScience Reviews, v. 123, p. 199-172.

Landing, E., Antcliffe, J.B., Geyer, G., Kouchinsky, A., Bowser, S.S., and Andreas, A., 2018, Early evolution of colonial animals (Ediacaran Evolutionary Radiation-Cambrian Evolutionary Radiation-Great Ordovician Biodiversification Interval): Earth-Science Reviews, v. 178, p. 105-135.

Li, L., Zhang, X., Yun, H., and Li, G., 2017, Complex hierarchical microstructure of Cambrian mollusk Pelagiella: Insight into early biomineralisation and evolution: Scientific Reports, v. 7, p. 1-11.

Li, Y., and Zhou, B., 1986, Discovery of old microfossil bivalves in China and its significance: Chinese Journal of Geology, p. 241-254 [in Chinese].

Lindberg, D.W., 2009, Monoplacophorans and the origin and relationships of mollusks: Evolution: Education and Outreach, v. 2, p. 191-203.

Lindsey, R.M., and Kier, W.M., 1984, The Paragastropoda: A proposal for a new class of Paleozoic Mollusca: Malacologia, v. 25, p. 241-254.

Linnaeus, C., 1758, Systema naturae per regna tria naturae (tenth edition): Stockholm, Laurentii Salvii.

Linnarsson, G., 1879, Om faunan i kalken med Conocoryphe exulsans ('Coronatuskalken'): Sveriges Geologiska Underökning Serie C, v. 35, p. 1-31 [in Swedish]

Mackinnon, D.I., 1985, New Zealand late middle Cambrian molluscs and the origin of Rostroconchia and Bivalvia: Alcheringa: An Australian Journal of Palaeontology, v. 9, p. 65-81.

Malinky, J.M., and Skovsted, C.B., 2004, Hyoliths and small shelly fossils from the lower Cambrian of North-East Greenland: Acta Palaeontologica Polonica, v. 49, p. 551-578.

Martí-Mus, M., Palacios, T., and Jensen, S., 2008, Size of the earliest molluscs: Did small helcionelloids grow to become large adults?: Geology, v. 36, p. $175-178$

Matthew, G.F., 1894, Illustrations of the fauna of the St. John Group: Transactions of the Royal Society of Canada, v. 11, p. 85-129.

Matthew, G.F., 1895, The Protolenus fauna: Transactions of the New York Academy of Sciences, v. 14, p. 101-153.

Matthew, G.F., 1902, Notes on Cambrian faunas: Transactions of the Royal Society of Canada, v. 84, p. 93-112.

Missarzhevsky, V.V., 1989, Oldest skeletal fossils and stratigraphy of Cambrian-Precambrian boundary beds: Trudy, Geologicheskiy institut, Akademiya nauk SSSR, v. 326, p. 1-91 [in Russian].

Missarzhevsky, V.V., and Mambetov, A.M., 1981, Stratigraphy and fauna of the Precambrian-Cambrian boundary beds of the Malyy Karatau: Trudy Ordena Trudovogo Krasnogo Znameni Geologicheskiy Institut Akademiya NAUK SSSR, v. 326, p. 1-90 [in Russian].

Mount, J.F., and Signor, P.W., 1992, Faunas and facies-fact and artifact. Paleoenvironmental controls on the distribution of early Cambrian faunas, in Lipps, J.H., and Signor, P.W. eds., Origins and Early Evolution of the Metazoa: New York, Plenum Press, p. 27-51.

Myrow, P.M., Pope, M.C., Goodge, J.W., Fischer, W., and Palmer, A.R., 2002, Depositional history of pre-Devonian strata and timing of Ross orogenic tectonism in the central Transantarctic Mountains, Antarctica: Geological Society of America Bulletin, v. 114, p. 1070-1088.

Narbonne, G.M., Myrow, P., Landing, E., and Anderson, M.M., 1991, A chondrophrine (medusoid hydrozoan) from the basal Cambrian (Placentian) of Newfoundland: Journal of Palaeontology, v. 65, p. 186-191.
Palmer, A., and Gatehouse, C., 1972, Early and middle Cambrian trilobites from Antarctica: U.S. Geological Survey Professional Paper 456-D, p. 1-36.

Palmer, A.R., and Rowell, A.J., 1995, Early Trilobites from the Shackleton Limestone of the Central Transantarctic Mountains: Journal of Paleontology, v. 45, p. 1-28.

Parkhaev, P.Y., 2000, The functional morphology of the Cambrian univalved mollusks-Helcionellids. 1: Paleontological Journal, v. 34, p. 392-399.

Parkhaev, P.Y., 2001, The functional morphology of the Cambrian univalved mollusks-Helcionellids: Paleontological Journal, v. 35, p. 470-475.

Parkhaev, P.Y., 2002, Phylogenesis and the system of the Cambrian univalved molluscs, v. 36, p. 25-36.

Parkhaev, P.Y., 2004a, Malacofauna of the lower Cambrian Bystraya Formation of Eastern Transbaikalia: Paleontological Journal, v. 38, p. 590-608.

Parkhaev, P.Y., 2004b, New data on the morphology of shell muscles in Cambrian helcionelloid mollusks: Paleontological Journal, v. 38, p. 254-256.

Parkhaev, P.Y., 2005, Two new species of Cambrian helcionelloid mollusks from the northern part of the Siberian Platform: Paleontological Journal, v. 39, p. 615-619.

Parkhaev, P.Y., 2007a, The Cambrian 'basement' of Gastropod evolution: Geological Society, London, Special Publications, v. 286, p. 415-421.

Parkhaev, P.Y., 2007b, Shell chirality in Cambrian gastropods and sinistral members of the genus Aldanella Vostokova 1962: Paleontological Journal, v. 41, p. $233-240$

Parkhaev, P.Y., 2008, The early Cambrian radiation of Mollusca, in Ponder, W., and Lindberg, D.R., eds., Phylogeny and Evolution of the Mollusca: Oakland, University of California Press, p. 33-69.

Parkhaev, P.Y., 2014, Protoconch morphology and peculiarities of the early ontogeny of the Cambrian helcionelloid molluscs, Paleontological Journal, v. 48, p. 369-379.

Parkhaev, P.Y., 2017a, On the position of archaeobranchians in the system of the class gastropoda: Paleontological Journal, v. 51, p. 3-12.

Parkhaev, P.Y., 2017b, Davidonia nom. nov., a new substitute name for a Cambrian gastropod genus: Paleontological Journal, v. 51, p. 574.

Parkhaev, P.Y., and Demidenko, Y.E., 2010, Zooproblematica and Mollusca from the lower Cambrian Meishucun Section (Yunnan, China) and taxonomy and systematics of the Cambrian small shelly fossils of China: Paleontological Journal, v. 44, p. 883-1161.

Paterson, J.R., and Brock, G.A., 2007, Early Cambrian trilobites from Angorichina, Flinders Ranges, South Australia, with a new assemblage from the Pararaia bunyerooensis Zone: Journal of Paleontology, v. 81, p. 116-142.

Paulsen, T.S., Encarnación, J., Grunow, A.M., Layer, P.W., and Watkeys, M., 2007, New age constraints for a short pulse in Ross orogen deformation triggered by East-West Gondwana suturing: Gondwana Research, v. 12, no. 4 , p. $417-427$.

Peel, J.S., 1991a, Functional morphology of the Class Helcionelloida nov., and the early evolution of the Mollusca, in Simonetta, A.M., and Conway Morris, S., eds., The Early Evolution of the Metazoa and the Significance of Problematic Taxa: Cambridge, Cambridge University Press, p. 157-177.

Peel, J.S., 1991b, The classes Tergomya and Helcionelloida, and early molluscan evolution: Grønlands Geologiske Undersøgelse, v. 161, p. 11-66.

Peel, J.S., 2003, A problematic cap-shaped metazoan from the lower Cambrian of Estonia: GFF, v. 125, p. 157-161

Peel, J.S., and Horný, R.J., 2004, A new problematic Early Ordovician univalve mollusc from France: Palaeontology, v. 47, no. 6, p. 1629-1639.

Peel, J.S., and Skovsted, C.B., 2005, Problematic cap-shaped fossils from the lower Cambrian of North-East Greenland: Paläontologische Zeitschrift, v. 79 , p. 461-470.

Pei, F., 1985, First discovery of Yochelcionella from the lower Cambrian of China and its significance: Acta Micropaleontologica Sinica, v. 2, p. 395400 [in Chinese with English abstract].

Peng, S., Babcock, L.E., and Cooper, R.A., 2012, The Cambrian Period, in Gradstein, F.M., Ogg, J.G., Schmitz, M., and Ogg, G., eds, The Geologic Timscale 2012: Amsterdam, Elsevier, p. 437-488.

Ponder, W.F., and Lindberg, D.R., 1997, Towards a phylogeny of gastropod molluscs: An analysis using morphological characters: Zoological Journal of the Linnean Society, v. 119, p. 83-265.

Rees, M.N., Pratt, B.R., and Rowell, A.J., 1989, Early Cambrian reefs, reef complexes, and associated lithofacies of the Shackleton Limestone, Transantarctic Mountains: Sedimentology, v. 36, p. 341-361.

Rode, A.L., Lieberman, B.S., and Rowell, A.J., 2003, A new early Cambrian bradoriid (Arthropoda) from East Antarctica: Journal of Paleontology, v. 77, p. 691-697.

Rowell, A.J., Rees, M.N., Cooper, R.A., and Pratt, B.R., 1988a, Early Paleozoic history of the central transantarctic mountains: Evidence from the Holyoake Range, Antarctica: New Zealand Journal of Geology and Geophysics, v. 31, p. 397-404.

Rowell, A.J., Evans, K.R., and Rees, M.N., 1988b, Fauna of the Shackleton Limestone: Antarctic Journal of the United States, v. 23, p. 13-14. 
Runnegar, B., 1981, Muscle scars, shell form and torsion in Cambrian and Ordovician molluscs: Lethaia, v. 12, p. 311-322.

Runnegar, B., 1983, Molluscan phylogeny revisited: Memoir of the Association of Australasian Palaeontologists, v. 1, p. 121-144.

Runnegar, B., and Bentley, C., 1983, Anatomy, ecology and affinities of the Australian early Cambrian bivalve Pojetaia runnegari Jell: Journal of Paleontology, v. 57, p. 73-92.

Runnegar, B., and Jell, P.A., 1976, Australian middle Cambrian molluscs and their bearing on early molluscan evolution: Alcheringa: An Australasian Journal of Palaeontology, v. 1, p. 109-138.

Runnegar, B., and Jell, P.A. 1980, Australian middle Cambrian molluscs: Corrections and additions: Alcheringa: An Australasian Journal of Palaeontology, v. 4, p. 111-113.

Runnegar, B., and Pojeta, J., 1974, Molluscan phylogeny: The paleontological viewpoint: Science, v. 186 , p. 311-317.

Salvini-Plawen, L. von, 1980, A reconstruction of systematics in the Mollusca (phylogeny and higher classification): Malacologia, v. 19, p. 249-278.

Schmidt, F., 1888: Über ein neuentdeckte unterkambrische Fauna: Memoires de L'Academie Imperiale des Sciences de St. Petersbourg, v. 7, p. 1-29 [in German].

Schuchert, C., and Dunbar, C.O., 1934, Stratigraphy of western Newfoundland: Memoir of the Geological Society of America, v. 1, p. 1-123.

Siveter, D.J., and Williams, M., 1997, Cambrian bradoriid and phosphatocopid arthropods of North America: Special Papers in Palaeontology, v. 57, p. $1-69$.

Skovsted, C.B., 2004, Mollusc fauna of the early Cambrian Bastion Formation of north-east Greenland: Bulletin of the Geological Society of Denmark, v. 51, p. 11-37.

Skovsted, C.B., 2006a, Small shelly fossils from the basal Emigrant Formation (Cambrian, uppermost Dyeran Stage) of Split Mountain, Nevada: Canadian Journal of Earth Sciences, v. 43, p. 487-496.

Skovsted, C.B., 2006b, Small shelly fauna from the upper lower Cambrian Bastion and Ella Island Fomations, North-East Greenland: Journal of Paleontology, v. 80, p. 1087-1112.

Skovsted, C.B., and Holmer, L.E., 2005, Early Cambrian brachiopods from North-East Greenland: Palaeontology, v. 48, p. 325-345.

Skovsted, C.B., and Peel, J.S., 2007, Small shelly fossils from the argillaceous facies of the lower Cambrian Forteau Formation of western Newfoundland: Acta Palaeontologica Polonica, v. 52, p. 729-748.

Skovsted, C.B., and Peel, J.S., 2010, Early Cambrian brachiopods and other shelly fossils from the basal Kinzers Formation of Pennsylvania: Journal of Paleontology, v. 84, p. 754-762.

Skovsted, C.B., Brock, G.A., and Paterson, J.R., 2006, Bivalved arthropods from the lower Cambrian Mernmerna Formation, Arrowie Basin, South Australia and their implications for identification of Cambrian 'small shelly fossils': Memoirs of the Association of Australasian Palaeontologists, v. 32, p. 7-41.

Skovsted, C.B., Betts, M. J., Topper, T.P., and Brock, G.A., 2015, The early Cambrian tommotiid genus Dailyatia from South Australia: Memoirs of the Association of Australasian Palaeontologists, v. 48, p. 1-117.

Smith, P.M., Brock, G.A., and Paterson, J.R., 2015, Fauna and biostratigraphy of the Cambrian (Series 2, Stage 4; Ordian) Tempe Formation (Pertaoorta Group), Amadeus Basin, Northern Territory: Alcheringa: An Australasian Journal of Palaeontology, v. 39, p. 40-70.

Steiner, M., Zhu, M., Weber, B., and Geyer, G., 2001, The lower Cambrian of eastern Yunnan: Trilobite based biostratigraphy and related faunas: Acat Palaeontologica Sinica, v. 40, p. 63-79.

Steiner, M., Li, G., and Zhu, M., 2004, Lower Cambrian small shelly faunas from Zhejiang (China) and their biostratigraphical implications: Progress in Natural Science, v. 13, p. 852-860.

Steiner, M., Li, G., Qian, Y., Zhu, M., and Erdtmann, B-D., 2007, Neoproterozoic to early Cambrian small shelly fossil assemblages and a revised biostratigraphic correlation of the Yangtze Platform (China): Palaeogeography, Palaeoclimatology Palaeoecology, v. 254, p. 67-99.

Steiner, M., Li, G., and Ergaliev, G., 2011, Toward a subdivision of the traditional 'lower Cambrian': Museum of North Arizona Bulletin, v. 67, p. 306-308

Tate, R., 1892, The Cambrian fossils of South Australia: Transactions of the Royal Society of South Australia, v. 15, p. 183-189.

Thiele, J., 1925, Gastropoden der deutschen Tiefsee-Expedition: II. Wissenschaftliche Evgebnisse der Deutschen Tiefsee-Expedition "Valdivia," v. 17, p. 35-382 [in German].

Topper, T.P., Brock, G.A., Skovsted, C.B., and Paterson, J.R., 2009, Shelly fossils from the lower Cambrian 'Pararaia bunyerooensis' Zone, Flinders Ranges, South Australia: Association of Australasian Palaeontologists Memoirs, v. 37, p. 199-246.

Topper, T.P., Skovsted, C.B., Brock, G.A., and Paterson, J.R., 2011, The oldest bivalved arthropods from the early Cambrian of East Gondwana:
Systematics, biostratigraphy and biogeography: Gondwana Research, v. 19 , p. $310-326$

Torsvik, T.H., and Cocks, L.R.M., 2013a, Gondwana from top to base in space and time: Gondwana Research, v. 24, p. 999-1030.

Torsvik, T.H., and Cocks, L.R.M., 2013b, New global palaeogeographical reconstructions for the early Palaeozoic and their generation: Geological Society of London Memoirs, v. 38, p. 5-24.

Vendrasco, M.J., and Checa, A.G., 2015, Shell microstructure and its inheritance in the calcitic helcionellid Mackinnonia: Estonian Journal of Earth Science, v. 64, p. 99-104.

Vendrasco, M.J., Li, G., Porter, S.M., and Fernandez, C.Z., 2009, New data on the enigmatic Ocruranus-Eohalobia group of early Cambrian small skeletal fossils: Palaeontology, v. 52, p. 1373-1396.

Vendrasco, M.J., Porter, S.M., Kouchinsky, A., Li, G., and Fernandez, C.Z., 2010, New data on molluscs and their shell microstructures from the middle Cambrian Gowers Formation, Australia: Palaeontology, v. 53, p. 97-135.

Vendrasco, M.J., Checa, A.M., and Kouchinsky, A.V., 2011, Shell microstructure of the early bivalve Pojetaia and the independent origin of nacre within the Mollusca: Palaeontology, v. 54, p. 825-850.

Vinther, J., 2015, The origins of molluscs: Palaeontology, v. 58, p. 19-34.

Vostokova, V.A., 1962, Cambrian gastropods from Siberian Platform and Taimyr: Statei po Paleontologii i Biostratigrafii, v. 28, p. 51-74 [in Russian].

Wenz, W., 1938, Handbuch der Paläozoologie; Gastropoda: Berlin, Handbuch der Paläozoologie, 256 p. [in German].

Wotte, T., 2006, New middle Cambrian molluscs from the Láncara Formation of the Cantabrian Mountains (north-western Spain): Revista Española de Paleontología, v. 21, p. 145-158.

Wotte, T., and Sundberg, F.A., 2017, Small shelly fossils from the Montezuman-Delmaran of the Great Basin in Nevada and California: Journal of Paleontology, v. 91, p. 883-901.

Wrona, R., 1989, Cambrian limestone erratics in the Tertiary glacio-marine sediments of King George Island, West Antarctica: Polish Polar Research, v. 10, p. $533-553$

Wrona, R., 2003, Early Cambrian molluscs from glacial erratics of King George Island, West Antarctica: Polish Polar Research, v. 24, p. 181-216.

Wrona, R., 2004, Cambrian microfossils from glacial erratics of King George Island, Antarctica: Acta Palaeontologica Polonica, v. 19, p. 13-56.

Wrona, R. 2009, Early Cambrian bradoriide and phosphatocopide arthropods from King George Island, West Antarctica: Biogeographic implications: Polish Polar Research, v. 30, p. 347-377.

Xing, Y., Ding, Q., Luo, H., He, T., and Wang, Y., 1984, The Sinian-Cambrian Boundary of China: Bulletin of the Institute of Geology, Chinese Academy of Geological Sciences, v. 10, p.1-262 [in Chinese].

Yang, B., Steiner, M., and Keupp, H., 2015, Early Cambrian palaeobiogeography of the Zhenba-Fangxian Block (South China): Independent terrane or part of the Yangtze Platform?: Gondwana Research, v. 28, p. 1543-1565.

Yochelson, E.L., and Gil Cid, D., 1984, Reevaluation of the systematic position of Scenella: Lethaia, v. 17, p. 331-340.

Yu, W., 1979, Earliest Cambrian monplacophorans and gastropods from Western Hubei with their biostratigraphical significance: Acta Palaeontologica Sinica, v. 18, p. 233-270 [in Chinese with English summary].

Yu, W., 1987a, New molluscan materials of the Tethys, in Mckenzie, K.G., ed., Proceedings of the International Symposium on Shallow Tethys 2: Rotterdam, A.A. Balkema.

Yu, W., 1987b, Yangtze micromolluscan fauna in Yangtze Region of China with notes on Precambrian-Cambrian boundary: Stratigraphy and Palaeontology of Systemic boundary in China, v. 1, p. 19-344 [in Chinese].

Yu, W., 1990, The first radiation of shelled molluscs: Palaeontologia Cathayana, v. 5, p. 139-190.

Yu, W, and Rong, Z-q., 1991, Lower Cambrian gastropods from Fangcheng County, Henan: Acta Micropalaeontologica Sinica, v. 3, p. 339-345.

Yun, H., Zhang, X., Li, L., Zhang, M., and Liu, W., 2016, Skeletal fossils and microfacies analysis of the lowermost Cambrian in the southwestern margin of the North China Platform: Journal of Asian Earth Sciences, v. 129, p. 54-66.

Zhang, X., et al., 2017, Challenges in defining the base of Cambrian Series 2 and Stage 3: Earth-Science Reviews, v. 172, p. 124-139.

Zhou, B., and Xiao, L., 1984, Early Cambrian monoplacophorans and gastropods from Huainan and Huoqiu Counties, Anhui Province, in Editorial Board of the Proceedings of Stratigraphy and Paleontology, Chinese Academy of Geological Sciences, eds., Proceedings of Stratigraphy and Paleontology, Volume 13: Beijing, Geological Publishing House, p. 125-140 [in Chinese with English abstract].

Accepted: 13 September 2018 